\section{EMBRYRIDDLE}

Aeronautical University

SCHOLARLY COMMONS
Journal of Aviation/Aerospace

Education \& Research

Volume 29

Number 2 JAAER 2020

Article 5

2020

\title{
Research Recommendations from the Airplane Simulation Transfer Literature
}

Jan G. Neal

Embry-Riddle Aeronautical University, nealc62@erau.edu

Stephanie G. Fussell PhD

Kent State University, sfussel2@kent.edu

Steven Hampton

Embry-Riddle Aeronautical University, hamptons@erau.edu

Follow this and additional works at: https://commons.erau.edu/jaaer

\section{Scholarly Commons Citation}

Neal, J. G., Fussell, S. G., \& Hampton, S. (2020). Research Recommendations from the Airplane Simulation Transfer Literature. Journal of Aviation/Aerospace Education \& Research, 29(2). https://doi.org/ 10.15394/jaaer.2020.1830

This Article is brought to you for free and open access by the Journals at Scholarly Commons. It has been accepted for inclusion in Journal of Aviation/Aerospace Education \& Research by an authorized administrator of Scholarly Commons. For more information, please contact commons@erau.edu. 
Modern flight simulators are a "more realistic, safe, efficient, flexible, and cost-effective way to develop pilot skills" (McLean, Lambeth, \& Mavin, 2016, p. 36; see also Valverde, 1968, 1973). The vital role of ground simulation devices in aviation is due to the complexity of learning to fly, inherent safety risk of the flight environment, high purchase and operation costs of aircraft, and growing demand for more pilots (International Civil Aviation Organization [ICAO], 2011). Accordingly, transfer researchers endeavor to validate the effectiveness of flight simulation training for this is the best way to reliably know what knowledge, skills, and abilities (KSAs) are worth training in a simulator.

Synthesis research, particularly systematic and meta-analytic reviews, can produce the first evidence about moderating variables and can be a source of potential hypotheses for future primary research (Cooper, 2010, p. 43). However, Smode, Hall, and Meyer (1966) made these salient observations about pilot training research, which are arguably still relevant today:

The body of findings simply does not contain the substance needed for resolving major problems in pilot training. Perhaps the basic reason for this has been the absence of systematic or programmatic assaults on the prevalent issues to be resolved. The major research needs have been known and expressed in one form or another for many years, but the research has not been structured in terms of these needs. Most often, there has been a sporadic "chipping away" at portions of the defined issues with no overall concepts of guidance enunciated by users, buyers, or researchers.... What has been studied has been dictated by the availability of apparatus and equipment and by task situations relatively easy to install. (p. 8) 
Perhaps these issues are unnoticed by researchers. Without a doubt, a contributing factor to the lack of a unified approach to the transfer of training research is the magnitude of literature. Cooper (2010) explains,

The number of journals in which relevant research might appear is generally far greater than those that a single scientist examines routinely. As early as 1971, Garvey and Griffith noted that scholars had lost the ability to keep abreast of all information relevant to their specialties through personal readings and journal subscriptions. (p. 61)

Logically, this concern is only going to become more significant with the persistent proliferation of research literature. More targeted inquiries are needed to develop a theory that ties together all of the fundamental principles of simulation transfer of training (McLean et al., 2016), but it is difficult for busy scholars to stay informed on current research, much less current, and future, research needs (Cooper, 2010). To facilitate this goal, Hays, Jacobs, Prince, and Salas (1992) assert quantitative literature reviews should summarize the empirical findings as well as the knowledge gaps where future research studies should focus.

The problem of interest in this study is the gaps in the empirical, flight simulation transfer literature. Empirical simulation research employs a true transfer or a quasi-transfer experimental design. With a true transfer design, one group receives simulator training with the treatment condition (experimental group), another group receives simulator training without the treatment (control group), and the performances of both groups are subsequently evaluated in the real aircraft (de Winter, Dodou, \& Mulder, 2012b, p. 167). With a quasi-transfer design, "(also called pseudo-transfer, in-simulator transfer, or simulator-to-simulator transfer), the [experiment] follows the same procedure as true transfer, with the difference that the transfer session is conducted in the simulator acting as a stand-in for the real aircraft" (de Winter et al., 2012b, p. 
167). The objective is to determine if the transfer outcomes are positive or negative.

Consequently, the focus of this literature review is the primary simulator transfer research investigating the acquisition, transfer, and maintenance of pilot KSAs.

The research question is:

- What are the recommendations for future research from the simulation experiments using a true transfer or a quasi-transfer design to study the near or far transfer of airplane flying knowledge, skills, or abilities among adults?

This paper presents specific research recommendations from a descriptive review of the airplane simulation transfer-of-training literature published from 2004 to 2019. It also presents a brief synopsis of each study selected for review, identifies the major research themes during this sampling frame, and situates the findings within the broader transfer literature to identify weaknesses and research gaps to inform future research. The Method section describes the selection criteria, coding process, and type of data collected. The Results section presents the summaries and recommendations from the simulation transfer of training meta-analytic reviews, systematic reviews, and experimental studies. (Table B2 in Appendix B presents the data collected from the primary research.) In the Discussion section, we offer vital takeaways and highlight potential gaps in the aviation transfer literature. We also present general recommendations and propose an agenda for future research. This study is relevant to researchers, practitioners, manufacturers, and regulators in the field of flight simulation training.

\section{Method}

To conduct a systematic review of the research literature on aviation simulation transfer of training, we began by selecting full-text papers written in English from open-access reference databases, research registers, and indexed journals published from 1973 to 2019. The initial 
document retrieval identified approximately 3,980 papers using keyword searches of the titles, abstracts, and articles. Search terms included "flight," "flight simulator," "simulator," "study," "training effectiveness," and "transfer of training." Eliminating non-research publications, such as editorials and book reviews, left 582 papers. Removing duplicates left 362 research articles for assessment of study eligibility.

In the next stage of the process, we delimited the literature to airplane-related research published since 2004 and transfer meta-analytic and systematic reviews published since 1973. Articles accepted for review had to meet the following criteria: (a) include only adult participants (i.e., $\geq 18$ years old), (b) utilize any ground simulation device for fixed-wing aircraft pilot training, (c) employ an empirical research design (i.e., true transfer, quasi-transfer, incremental transfer), and (d) examine transfer of training effectiveness (i.e., compare outcome variables across experimental conditions). That left 34 papers selected for qualitative synthesis. Figure 1 illustrates the research actions at each stage of the process. 


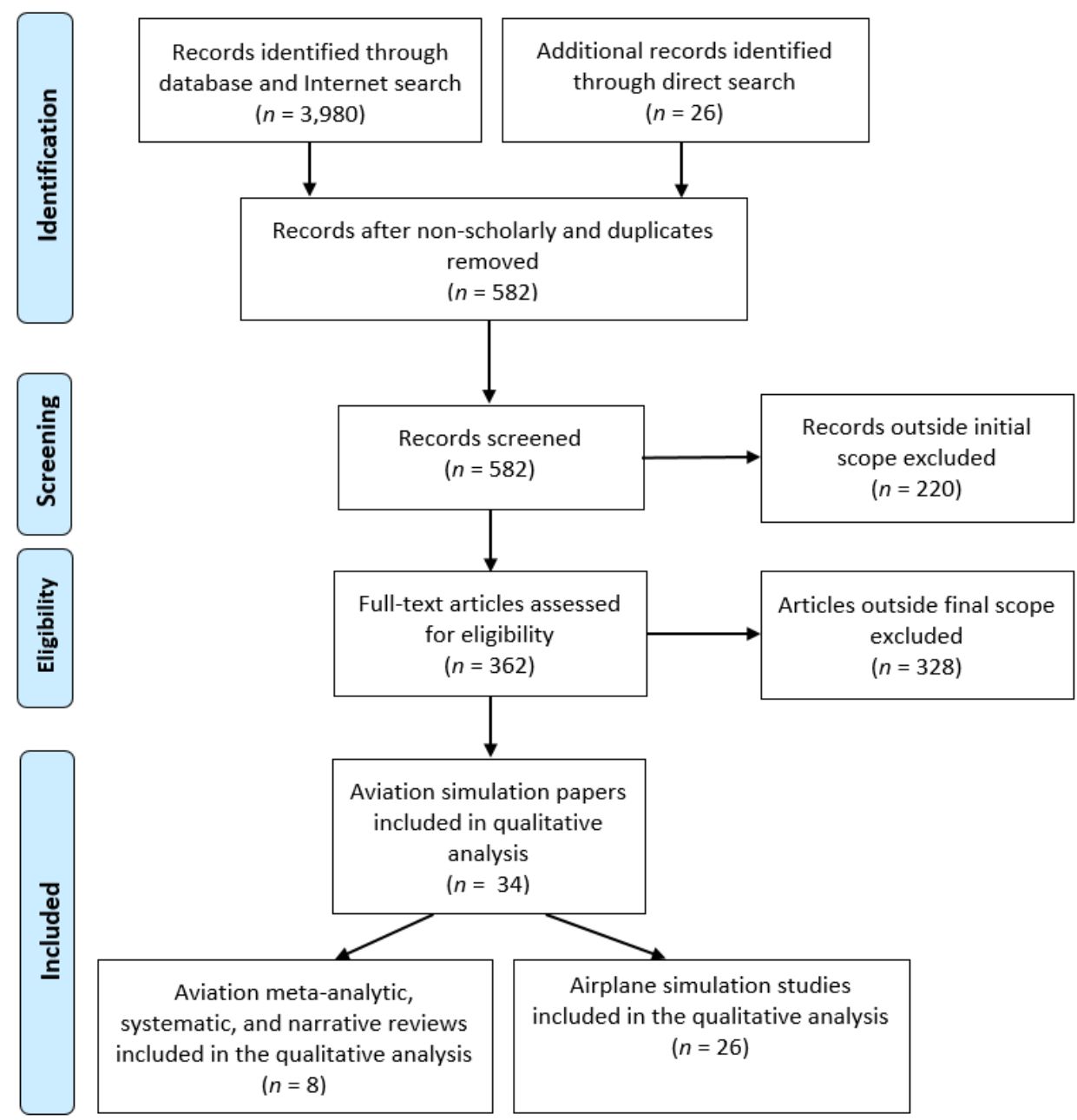

Figure 1. Research flow diagram.

The double coding process involved the independent recording of the data from each source and then comparing the results (Cooper, 2010). Collected data included the source reference, retrieval location (e.g., database, direct search), aviation domain of interest, topic theme, type of transfer (i.e., true transfer, quasi-transfer, incremental transfer), research design, number of participants, participant experience, skills trained/assessed, training/testing devices, independent variables, dependent measures, data collection method, type of analysis, reported effect size, chief results, and recommendations. (See Appendix A for the definitions of key terms.) 
Although this review includes civil, commercial, and military aviation research conducted outside of the U.S., the primary frame of reference is the research studies involving airplane flight simulators and airplane flight-training devices approved and operated under U.S. regulations. Regulatory agencies (e.g., FAA) establish the regulations and guidance for (a) certifying flight simulation training devices (FSTDs); (b) approving knowledge, skills, and procedures taught in FSTDs; and (c) limiting the amount of FSTD time used in place of actual flight time in an aircraft for pilot training, experience, and currency. Title 14 Parts 60, 61, and 141 of the U.S. Code of Federal Regulations (FAA, 2018b) provide the regulatory policies and guidance for advanced aviation training devices (AATDs), basic aviation training devices (BATDs), and FSTDs or full flight simulators (FFSs). (See Appendix A for the main categories of modern aviation simulators and their definitions.) These U.S. regulations comply with ICAO standards and recommended practices (FAA Flight Simulation Training Device Initial and Continuing Qualification and Use Rule, 2008). This investigation contributes to the field of flight simulation training, which is relevant to researchers and practitioners. It also has implications for the future development of AATDs, BATDs, and FSTDs, which are essential to flight simulation manufacturers and regulators.

To avoid redundancy, we only offer one summary for works published in different years by the same author(s) that covers the same research study, and we include an earlier publication covering the same research only when it provides more comprehensive descriptions or data. We present these works grouped according to the lowest level device used (BATD, AATD, or FFS) and from the earliest to the latest published, which offers a timeline of sorts to see the trend of research directions over time in these research areas. Similarly, in most cases, the order of the recommendations follows the sequence in which they occur or in which we discern them in the 
article. The hierarchy does not imply importance or significance. Nor does inclusion imply the recommendation is feasible; that is beyond the scope of this paper. We map the recommendations from the eight aviation meta-analytic, systematic, and narrative reviews to the aviation transfer studies to identify gaps in the aviation transfer literature. (See Table B1 for the recommendations from the seminal aviation reviews aligned with the primary aviation studies.) It is important to note our agreement on all but three of the alignments and our handling of those discrepancies through consensus.

\section{Results}

We begin with the results from the seminal meta-analytic, systematic, and narrative reviews published since 1973. We did not find any such works after 2013. Then we provide abstracted summaries and recommendations from the 26 aviation simulation transfer studies published within the civil, commercial, and military aviation domains between 2004 and 2018 . We did not find any studies published in 2008 or 2019 that met the eligibility criteria for inclusion. Our review ends with the four general transfer meta-analyses published in 2009, 2010, 2013, and 2018 in which to situate the aviation transfer literature.

\section{Narrative, Meta-Analytic, and Systematic Reviews of the Aviation Transfer Literature}

In this section, we present summaries and the number of recommendations from each of the eight meta-analytic and systematic reviews. They comprise the seminal aviation, simulation transfer literature published between 1973 and 2013. Their primary focus is flight simulator training for fixed-wing aircraft, but some of the works also encompass rotorcraft training.

Valverde (1973). In this seminal narrative review, A Review of Flight Simulator Transfer of Training Studies, the author examines the technical reports from 24 fixed-wing $(n=21)$ and rotary-wing $(n=3)$ transfer of training studies published between 1949 and 1971 in the 
Psychological Abstracts of the American Psychological Association and available through the Defense Documentation Center (p. 513). He identifies disparities in the literature findings presumably due to "variables not assessed in the experiments" (p. 520). They pertain to subjective criterion measures, pilot (subject) performance matching, the role of the simulator instructor and simulator fidelity, (p. 520), and instructional sequence (block vs. alternating) of the simulator and aircraft training (p. 521). There are three recommendations for future research (see Table B1).

Williges, Roscoe, and Williges (1973). In this seminal review, Synthetic Flight Training Revisited, the authors examine the ground-based flight simulation literature published between 1947 and 1973 and identify critical issues and research needs concerning the development and application of ground-based simulation training devices (p. 543). There are 17 recommendations (see Table B1).

Hays, Jacobs, Prince, and Salas (1992); Jacobs, Prince, Hays, and Salas (1990). In this meta-analysis of the experimental military literature from 1957 to 1986, Flight Simulator Training Effectiveness: A Meta-Analysis, the authors examine 26 true-transfer and quasi-transfer studies: 19 jet experiments and seven helicopter experiments (Hays et al., 1992, p. 1). The conclusions prompt 13 recommendations for future research on fixed-wing aircraft, including improvements in the transfer research literature (see Table B1).

Carretta and Dunlap (1998). In this military analysis, Transfer of Training Effectiveness in Flight Simulation: 1986 to 1997, the authors review 13 articles, conference papers, and technical reports that address training transfer from the simulator to the aircraft. The majority show training simulators used for landing, bombing, and instrument flight skills. Some of the studies report improvement in training performance up to about 25 missions, after which it 
levels off. Several of the studies suggest positive transfer might not depend on high fidelity or whole-task training (p. ii). The authors contend there is a shortage of true transfer studies, and many researchers fail to provide adequate details on the simulator fidelity, research methods, and training characteristics. They propose two directions for future research (see Table B1).

Rantanen and Talleur (2005). In this analysis, Incremental Transfer and Cost Effectiveness of Ground-Based Flight Trainers in University Aviation Programs, the authors review 19 true transfer and incremental transfer studies on fixed-wing and rotary-wing aircraft training using PCATDs published between 1940 and 2005 by the FAA, U.S. military, and the University of Illinois (p. 764). The authors' discussion and conclusions prompt nine recommendations for future research (see Table B1).

Vaden and Hall (2005); Vaden (2002). In this meta-analysis, The Effect of Simulator Platform Motion on Pilot Training Transfer: A Meta-Analysis (Vaden \& Hall, 2005; Vaden, 2002), the authors examine four true-transfer simulation studies that used fixed-wing aircraft and three quasi-transfer simulation studies published between 1963 and 2000 that used independent samples with motion and no-motion simulator conditions (Vaden, 2002, p. 20; Vaden \& Hall, 2005, p. 381). There are five recommendations for future research (see Table B1).

Bürki-Cohen, Sparko, and Bellman (2011). In this analysis, Flight Simulator Motion Literature Pertinent to Airline-Pilot Recurrent Training and Evaluation, the authors synthesize motion meta-analyses published between 1999 and 2012. They discuss the findings and arguments in the seven studies analyzed by Vaden and Hall (2005), one transfer study by van der Pal (1999), 24 studies analyzed by de Winter et al. (2012a, 2012b), and four Volpe studies (Bürki-Cohen \& Go, 2005; Go, Bürki-Cohen, Chung, Schroeder, Saillant, Jacobs, \& Longridge, 
2003; Go, Bürki-Cohen, \& Soja, 2000; Sparko, Bürki-Cohen, \& Go, 2010). The authors' observations prompt two recommendations for future research (see Table B1).

de Winter, Dodou, and Mulder (2012a, 2012b). In this meta-analysis, Training Effectiveness of Whole Body Flight Simulation Motion: A Comprehensive Meta-Analysis, the authors calculate 24 effect sizes from fixed-wing and rotary-wing transfer and quasi-transfer experiments published between 1963 and 2011 that used whole-body simulator motion as the independent variable (p. 164). They examine the effects of moderating variables of flight experience, type of task trained, and the experimental design (p. 169). There are three recommendations for future research (see Table B1).

\section{Fixed-Wing Simulation Transfer Studies}

This section presents the key results of this research. Our search of the aviation, simulation transfer literature retrieved 26 empirical studies published since 2004 that satisfy the inclusion criteria. This body of literature includes 16 quasi-transfer studies and 10 true transfer studies (including one incremental transfer study). These primary transfer studies are presented (grouped) by the lowest level of simulation device employed. The collected data include the authors, article title, topic theme, type of transfer, research design, participants, participant experience, skills assessed, simulation devices, airplane type, independent variables, dependent measures, data collection, analysis, effect size, and chief results (see Table B2). Recommendations follow each summary.

\section{Basic aviation training devices and personal computer-based aviation training}

devices. This section presents eight investigations that employed a BATD or PCATD as the lowest level of simulation in the investigation. 
Taylor, Talleur, Rantanen, and Emanuel (2004). In this transfer study, The Effectiveness of a Personal Computer Aviation Training Device (PCATD), a Flight Training Device (FTD), and an Airplane in Conducting Instrument Proficiency Checks, the researchers compare performance evaluations of 75 pilots receiving Instrument Proficiency Checks (IPC). The researchers compare the IPC\#1 performances in an Elite PCATD, a Frasca 141 FTD, and a Beechcraft Sundowner (BE-C23) airplane with IPC \#2 performances in the BE-C23 aircraft. They use a multi-group design with 25 participants in each group. Chi-square tests of the pass/fail rate ratio, maneuvering performance, and maneuvering elements measurements show no significant differences in instrument pilot performance for IPC \#1 administered in a PCATD, FTD, or a BE-C23 compared to the IPC \#2 performance in the BE-C23 (p. 1). There are three recommendations for future research:

1. Considering IPC \#1 does not predict performance in IPC \#2, investigate the effectiveness of using PCATDs and FTDs for administering the IPC (p. 4).

2. Research whether IPC failures relate to the lack of familiarity with the simulation device when using fixed training trials as opposed to training to criterion (p. 4).

3. Investigate the benefits of requiring periodic IPCs to validate instrument proficiency in conjunction with the existing currency requirements and customizing the content of the IPC and the recency experience requirements to the kind of flight activities the pilot engages in regularly (p. 5).

McDermott (2005). In this quasi-transfer experiment using a between-subjects design, $A$ Comparison of the Effectiveness of a Personal Computer-Based Aircraft Training Device and a Flight Training Device at Improving Pilot Instrument Proficiency: A Case Study in Leading Regulatory Change in Aviation Education, the researcher compares the effectiveness of two 
aviation simulation devices for maintaining instrument pilot proficiency (p. 36). Instrument rated pilots $(n=63)$ practiced instrument rating proficiency standards in an FTD or a PCATD before completing a posttest in an FTD. The conclusions prompt five recommendations:

1. Establish regulations on computer-based software and hardware for training that meets experience requirements (p. 59).

2. Address affordability concerns about utilizing computer-based software and hardware for training (p. 60).

3. Examine training transfer from the simulator to the aircraft and the effects that occur when the simulator does not mimic the airplane (pp. 60, 67).

4. Examine moderating factors (e.g., age, gender, recent flight experience) that may influence instrument proficiency maintenance (p. 67).

5. Consider creating an electronically-linked online database to PCATDs for better oversight of instrument proficiency (p. 68).

Roessingh (2005). In this true transfer experiment, Transfer of Manual Flying Skills from PC-Based Simulation to Actual Flight-Comparison of In-Flight Measured Data and Instructor Ratings, the researcher investigates whether complex (aerobatic) manual flying skills (i.e., loop, Immelmann, inverted flight, slow roll, \& split S) learned during PC-based simulated flight training transfers to a Bellanca Super Decathlon fixed-wing aircraft. Aircraft data include altitude, indicated airspeed, type of maneuver, and the three orientation angles, angular rates, and linear accelerations) electronically recorded during the flight. He splits participants (21 experienced commercial pilot students with no aerobatic experience) into three balanced groups of eight based on their scores on the Aiming Screening Test that predicts success on complex tasks. The participants are randomly assigned to either routine training (control group), ground 
training with standard PC configuration, or ground training with extra PC features (p. 71). The conclusions prompt three recommendations for future research:

1. Research whether PC simulation is a useful automatic briefing tool and if it saves flight-instructor time (p. 88).

2. Research whether less nonspecific or more efficient use of flying time increases training transfer for procedural tasks (p. 88).

3. Investigate an empirical basis for the 12 additional qualification features (radio, flaps, propellers, etc.) of PCATDs; BATDs; and AATDs; Level 1, 2, and 3 FTDs for instrument flight simulation (see Koonce \& Bramble, 1998) described under FAA Advisory Circular 61-136 (p. 87).

Taylor, Talleur, Emanuel, and Rantanen (2005). In this multi-year, incremental truetransfer study, Transfer of Training Effectiveness of a Flight Training Device (FTD), the researchers investigate the point at which additional training using a Frasca 141 FTD and an ELITE PCATD is no longer advantageous for basic and instrument flight training (Abstract). The research method is a multi-group experimental design (four FTD groups, a PCATD group, and a control group). The dependent measures are the number of trials to reach the specific completion standards for specific instrument tasks, time to complete each flight lesson in the airplane, time to accomplish a successful evaluation flight, and the total course completion time in the aircraft (p. 736). Only 106 of the private pilot students completed the study, resulting in 15 and 20 participants in each of six groups that completed the 14 CFR Part 141 program (p. 736). The authors calculate the effects of the experimental treatment for the means of the 
dependent measures (transfer effectiveness ratio ${ }^{1}$ [TER], incremental transfer effectiveness ratio ${ }^{2}$ [ITER], percent transfer). The results show the FTD and PCATD are beneficial for instrument training, but the PCATD is only effective for the non-directional beacon instrument task (p. 738). However, they admit the low power of the ANOVA makes it impossible to conclude instrument training in the FTD offers significant savings (trials, time) over the aircraft training alone (p. 739). They provide three recommendations for future research:

1. If 5 hours of the 10 hours of PCATD time permitted by the FAA is most effective in training instruments tasks, investigate where flight schools could use the additional 5 hours most effectively in a flight curriculum (p. 739).

2. Investigate if PCATDs are effective for learning cross-country procedures where there is the opportunity of a one-to-one transfer of training for time (p. 739).

3. Determine the point in time or number of trials when further training in an FTD and PCATD becomes no longer beneficial (p. 739).

Nullmeyer, Spiker, Golas, Logan, and Clemons (2006). In this military, proof-ofconcept true-transfer study, The Effectiveness of a PC-Based C-130 Crew Resource Management Aircrew Training Device, the researchers evaluate the effectiveness of a low-cost, PC-based Aircrew Training Device (PC-ATD). The PC-ATD is designed to elicit crew resource management (CRM), aircrew situational awareness (SA), formation procedures, coordinated

\footnotetext{
${ }^{1} T E R=\frac{T_{c}-T_{e}}{X_{e}} ;$ where $T_{c}$ is the amount of airborne time needed by a control group; $T_{e}$ is the amount of
} airborne time needed by an experimental group to reach a specific criterion, and $X_{e}$ is the time spent in the training device. This value equates the number of hours spent in the trainer to equivalent training in an aircraft (Allerton, 2009, p. 12).

${ }^{2}$ ITER $=\frac{Y_{x-\Delta x}-Y_{x}}{\Delta_{x}} ;$ where $Y_{x-\Delta x}$ is the time required to reach a performance criterion by a group having received $x-\Delta_{x}$ units of training, $Y_{x}$ is the time required to reach a performance criterion by a group having received $\Delta_{x}$ units of training and $\Delta_{x}$ is the incremental unit of time (Allerton, 2009, p. 13). 
crew response behaviors, and threat recognition/reaction associated with airdrop missions in C130 aircraft while operating under instrument flight rules (IFR) and visual flight rules (VFR) [pp. 7-8]. The research method is a between-groups experimental design with 22 participants (i.e., 11 right-seat pilots who were formally co-pilots and 11 student navigators), none with previous C130 or airdrop flight experience (p. 10). Before performing in the C-130, five student navigators and six co-pilots (treatment group) compete 4 hours of training in the PC-ATD while the other six student navigators and five co-pilots do not receive any training in the PC-ATD (control group) [p. 10]. The researchers compare group performance on six dependent measures (CRM skills) from user feedback, instructor ratings, and aircrew training records (p. 17). They present two recommendations:

1. Use behaviorally anchored participant performance data (e.g., student records) in a multi-level research approach to evaluate training effectiveness (p. 19).

2. Examine the return on investment and potential flight hour reduction when a high fidelity PCATD is utilized (p. 19).

Rogers, Boquet, Howell, and DeJohn (2009, 2010). In this true-transfer experiment using a 2 x 4 repeated-measures factorial design, An Experiment to Evaluate Transfer of LowCost Simulator-Based Upset-Recovery Training (Rogers et al., 2009; see also Leland, Rogers, Boquet, \& Glaser, 2009), the researchers investigate skill transfer from Microsoft Flight Simulator ${ }^{(M F S)} 2002$ desktop software. The participants are 51 instrumented-rated private pilots at Embry-Riddle Aeronautical University (ERAU)—a Part 141 flight school—with no previous aerobatic flight experience nor any upset-recovery training beyond what the FAA mandates for the private pilot license (pp. 1-2). The experimental group of 28 participants receives $10 \mathrm{hrs}$ of upset-recovery instruction in the classroom and $10 \mathrm{hrs}$ of training on the MFS 
software, and the control group of 30 participants does not undergo any upset-recovery instruction or training (p. 2). Each participant undergoes testing in four recovery situations in a Beech Bonanza airplane in Phase 1 and a Super Decathlon aerobatic trainer in Phase 2 to determine if upset-recovery training with the low-fidelity flight simulator increases the probability of pilot recovery from an upset condition during a flight (pp. 2-3). The independent variables are degree-of-training (trained or untrained) and upset attitude (nose-low upright, noselow inverted, nose-high upright, nose-high inverted) [p. 6]. The dependent variables are altitude loss (feet), maximum G-force in dive pullout, minimum G-force unloading in rolls, number of seconds to the first throttle response, number of seconds to first roll response, and number of seconds to recover (p. 6). The authors provide six recommendations:

1. Determine if a superior flight simulation device would produce better results (p. 10).

2. Perform an experiment using $5 \mathrm{hrs}$ of upset-recovery training in a centrifugal flight simulator and compare the results with this study (p. 11).

3. Research the transfer effectiveness of upset training in a motion-based flight simulator capable of generating continuous $\mathrm{G}$ forces (pp. 11, 15).

4. Repeat the Rogers et al. 2009 experiment but omit the simulator training (Rogers et al., 2010, p. 162).

5. Require aerobatic experience in a light airplane as part of the requirements for a commercial pilot license and an ATP rating (Rogers et al., 2010, p. 167).

6. Investigate whether experienced airline pilots would react the same because their aerodynamic theory study would not be as current and because many would not have flown a light aircraft for many years (Rogers et al., 2010, p. 167). 
Leland, Rogers, Boquet, and Glaser (2009). In this true-transfer study utilizing a 3 x 4 repeated measures factorial design, An Experiment to Evaluate Transfer of Upset-Recovery Training Conducted Using Two Different Flight Simulation Devices, the researchers extend the Rogers et al. (2009) study. The researchers use the Environmental Tectonics' GL2000, a highend centrifuge motion-based flight simulator capable of continuous G-forces (p. 5) and the Microsoft ${ }^{\circledR}$ Flight Simulator running on desktop computers by adding another level to the independent variable degree-of-training (p. 5). The objective is to determine the value-added from upset recovery training in the GL2000 (p. 5). Group size varies between 17 and 26 pilots per group (p. 6). The authors use MANOVA to detect significant differences among groups on the four upset conditions, pairwise $t$-tests between every two groups to determine significant altitude loss differences, and ANOVAs on each dependent variable to detect significant differences between groups (pp. 7-8). There is one recommendation:

1. Repeat the Leland et al. (2009) upset recovery transfer experiment, but extend the training period to 3 days and use $1 / 2$ hr-GL2000 training sessions and alternate planetary motion sessions with non-motion sessions ( $5 \mathrm{hrs}$ of simulator time) based on how each participant tolerates the $\mathrm{G}$ forces and conduct $5 \mathrm{hrs}$ of recovery training using the MFS software instead of aerobatic training (p. 11).

Reweti (2014). In this quasi-transfer study, PC-based Aviation Training Devices for Pilot Training in Visual Flight Rules Procedures: Development, Validation and Effectiveness, the researcher investigates whether the Level 6, Frasca TruFlight \& Navigational Procedures Trainer (FNTP II) is significantly more effective than the low-cost SAV2 PCATD. The researcher measures the performance of two different pilot cohorts ( $n=93$ and $n=56)$ of mixed flight experience (ab-initio students to ATP pilots) on a standard VFR traffic pattern (i.e., overhead 
rejoin procedure) in a simulated Piper Cherokee (PA28) of Cessna 172 airplane (pp. 219-222). The author provides five recommendations for future research:

1. Investigate the transfer effectiveness of overlaying an opaque airspace boundary as a 3D-computer graphic onto the synthetic terrain of a PCATD for training cross-country navigation and landmark navigation in general (p. 364).

2. Conduct a longitudinal study evaluating pilot performance in a PCATD with pilot performance in a flight-training course to analyze the predictive powers of the PCATD pilot selection practical test (p. 364).

3. Conduct more research on the types of simulation scenarios developed with Scenario Builder software (or similar software) for the Diamond (DA) 40 PCATD to determine which scenario-based training is most effective (p. 365).

4. Research the effectiveness of flight schools incorporating the Virtual Air Traffic Simulation Network (VATSIM) in their training curriculum (p. 365).

5. Research the effectiveness of using the low-cost, COTS hydraulic joystick flight controls in a CAANZ-certified PCATD (p. 365).

Reweti, Gilbey, and Jeffrey (2017). This quasi-transfer experiment, Efficacy of Low-Cost PC-Based Aviation Training Devices, investigates whether PCATDs with improved visual fidelity are effective in training skills related to VFR procedures and navigation (p. 128). The researchers calculate significant differences between the pre-test and posttest scores of 93 pilots of mixed flight experience (ab-initio students to ATP pilots) on outcome variables of pitch, bank, total variable, altitude, indicated airspeed, heading, glide slope, and overhead rejoin pattern on both the Frasca TruFlight FTD and the PCATD configured as a PA-28 Piper Warrior aircraft (pp. 131-138). There is one recommendation for future research: 
1. Compare the transfer effectiveness of a PCATD and an FTD for other VFR tasks (e.g., forced landing after take-off, low-level navigation exercises) [p. 128].

Advanced aviation training devices and flight training devices. This section presents the nine transfer studies that employed an AATD or FTD as the lowest level of simulation in the investigation.

Macchiarella, Arban, and Doherty (2006); Macchiarella, Brady, and Lyon (2008). In this longitudinal true-transfer experiment, Transfer of Training from Flight Training Devices to Flight for Ab-Initio Pilots (Macchiarella et al., 2006), a transfer effectiveness ratio (TER) is used to compare two groups of ab initio flight students. Thirty-eight ab initio flight students completed $45.5 \%$ of their private pilot flight training in a Level 6 "Plus" Frasca 141 FTD and the balance in a Cessna 172S "Skyhawk" (experimental group) or all of their training in the Skyhawk (control group) [p. 302]. The TERs for 34 practical test standard (PTS) tasks (dependent variables) reveal positive transfer on 33 PTS tasks and the experimental group achieving the performance standards in fewer trials than the control group (pp. 303-305). Posthoc analysis indicates procedural similarity, the difficulty of the task, dynamic flight environment, visual fidelity, and visual scanning and response are potential causal factors affecting training transfer (pp. 310-311). There are five recommendations:

1. Research the broader application of FTDs and further refinement of an FTD-based flight curriculum (Macchiarella et al., 2008, p. 74).

2. Research the cognitive fidelity of the synthetic flight-training environment enhanced with virtual air traffic (VAT) and voice-recognition, interactive virtual air traffic controllers (Macchiarella et al., 2008, p. 72)

3. Research the effects of FTD visual system brightness on training transfer (p. 72). 
4. Investigate the enhancement of virtual weather in the FTDs (Macchiarella et al., 2008, p. 74).

5. Research whether students who learn to fly mostly using an FTD gain a better ability to verify aircraft state while visually scanning aircraft displays (Macchiarella et al., 2008, p. 74).

Cardullo, Stanco, Kelly, Houck, and Grube (2011). In this quasi-transfer of training experiment, A Transfer of Training Study of Control Loader Dynamics, the researchers evaluate the performance of 20 subjects (10 in each group) on a simple (non-flying) roll-axis disturbance nullification task using the Generic Flight Deck (GFD) simulator in the Cockpit Motion Facility (CMF) at the NASA Langley Research Center (p. 6). The researchers alter the variables for a low-fidelity control loader based on a Logitech Force 3D Pro gaming joystick and the GFD simulator with the high-fidelity control loader system representing the real vehicle (p. 6). The subjects perform the four phases of the experiment (i.e., familiarization, evaluation, training, and transfer) on either the high-fidelity control loader simulation or the low-fidelity control inceptor simulation before transferring to the high-fidelity control loader simulation where recordings of root mean square (RMS) tracking error and RMS control inceptor deflection occur during each 30-second run (p. 13). There is one recommendation:

1. Repeat a series of this experiment to obtain an extensive data set for analysis (p. 16).

Donderi, Niall, Fish, and Goldstein (2012). In this quasi-transfer study using a withinsubject research design, Above-Real-Time Training (ARTT) Improves Transfer to a Simulated Flight Control Task, the researchers investigate above-real-time-training (ARTT) among visualmotor training methods by measuring the effects of ARTT speed and screen resolution on a single-screen PC-based, simulated F-18A flight-control task performed by 54 non-pilot 
university participants (pp. 469-470). The researchers vary screen resolution between participants and change training speed factorially (independent variables) over two different sessions. All of the study participants complete the pretest and posttest trials at high resolution and criterion speed (i.e., 900 knots). Based on correlations and MANCOVA analyses, performance results are best for the participants using high screen resolution and a training regime of ARTT training followed by criterion speed training (p. 379). The findings prompt two recommendations for future research:

1. Assess transfer effectiveness to the criterion task for visual-motor skills by using a quasi-transfer design and employing high-resolution displays and ARTT training trials followed by high-resolution criterion speed training trials (p. 477).

2. Research whether ARTT can increase training speed to match the subjective speed of the criterion task and if varying ARTT with criterion-speed training produces contextual interference that improves transfer (p. 478).

Sparko, Bürki-Cohen, and Go (2010). In this between-groups quasi-transfer experiment, Transfer of Training from a Full-Flight Simulator vs. a High Level Flight Training Device with a Dynamic Seat, the fourth in the series of the Volpe study (p. 27), the researchers summarize the latest motion study by the FAA/Volpe Center for Simulator Flight Fidelity Requirements Program (p. 1). They compare the flight precision and control inputs of 20 commercial pilots with low Joint Aviation Requirements (JAR-25) large airplane experience to 20 similarly lowJAR-25-experienced pilots. One group receives training on responding correctly to enginefailures during takeoff and performing manually flown engine-out landings both with and without inclement weather in the Thompson Training \& Simulation FFS with 6 degrees-of- 
freedom (DOF). The other groups train on the same maneuvers/scenarios in the Mechtronix FFT with a 1 DOF dynamic seat (FFT-X) [pp. 3-6]. The conclusions prompt two recommendations:

1. Compute effects sizes for this study to quantify differences between the FFS-trained and FFT-trained pilots (p. 28).

2. Research whether 1 DOF seat motion systems deliver the same qualitative level of motion cues as full-flight systems using the same flight performance data obtained from this study (pp. 28, 38).

Mulder, Zaal, Pool, Damveld, and van Paassen (2013). In this quasi-transfer study, $A$ Cybernetic Approach to Assess Simulator Fidelity: Looking Back and Looking Forward, the researchers provide an overview of the chief findings of the 2006-2012 VIDI project. The research was designed to quantify fidelity of simulator operation based on objective measurements of pilot control behaviors and how they become altered by diminished motion cue fidelity in flight simulators (p. 1). There are two recommendations:

1. Conduct research that extends work on multimodal pilot-control behavior in actual flying tasks by investigating the (a) feedback-feedforward structure of pilot mental models elicited by well-known and predictable target signals; (b) outer-loop, innerloop, and multiple-loop pilot-control tasks; and (c) presence of out-of-the-window view providing aircraft motion information (p. 6).

2. Develop pilot models using a cybernetic approach (e.g., time-varying and non-linear mental models) for more realistic simulation of flight tasks and quantify the effectiveness of the level of skill acquisition, transfer, and retention from simulator training to improve training programs and simulation devices (p. 8). 
Nieuwenhuizen, Mulder, van Paassen, and Bülthoff (2013). In this transfer experiment, Influences of Simulator Motion System Characteristics on Pilot Control Behavior, the researchers investigate motion system characteristics by modeling a simulator with limited capabilities (MPI Stewart platform) on a high-end SIMONA Research Simulator. They identify pilot perception and control behavior among nine experienced participants on a control task (i.e., a closed-loop pitch-tracking task with disturbances) [p. 667]. There are two recommendations for future research:

1. Research different time delays because they influence the phase lag of motion cues separately from the decreased magnitude of motion cues (p. 675).

2. Investigate the use of extra bandwidth settings to determine the minimum requirements to obtain value from motion cues (p. 675).

Grundy, Nazar, O'Malley, Mohrenshildt, and Shedden (2016). In this quasi-transfer study, The Effectiveness of Simulator Motion in the Transfer of Performance on a Tracking Task Is Influenced by Vision and Motion Disturbance Cues, the researchers investigate whether motion disturbance (turbulence) improves performance over visual disturbances and results in better transfer of training. Seventy-five university students tested on five different tracking tasks conditions after simulator training (p. 547). There are four recommendations for future research:

1. Research whether visual turbulence during training sufficiently provokes changes similar to other types of motion turbulence and reduces the time needed in a fullmotion simulator (p. 546).

2. Investigate whether motion sickness and sopite syndrome (i.e., drowsiness that occurs after experiencing prolonged periods of motion) influence performance on simulator tracking tasks (pp. 557-558). 
3. Investigate whether the addition of turbulence contributes to more physical or visual fatigue on simulator tracking tasks (p. 558).

4. Extend this research by replicating this study with experienced pilots to determine how motion and turbulence affect training transfer (p. 558).

Koglbauer (2016). In this quasi-transfer study using a between-subjects design, Simulator Training Improves Pilots' Procedural Memory and Generalization of Behavior in Critical Flight Situations, the researcher examines the effect of simulator training on procedural memory as well as generalization of behavior in new situations (p. 357). The training effects for the technical recovery procedure of unusual attitudes in a fixed-base aircraft trainer (the author does not specify the type) for 31 pilots with no aerobatic experience is evaluated. She assigns the pilots to a training group or a control group, and both groups receive a written and oral procedural briefing and a recovery demonstration in a Pitts S-2B aircraft, and then complete a posttest in a flight simulator. The performance measurements recorded for all participants include recovery ratings and task completion time. The author offers one recommendation:

1. Conduct transfer research that provides for more variations in the maneuvers selected for training (p. 364).

McLean, Lambeth, and Mavin (2016). In this transfer study, The Use of Simulation in Ab Initio Pilot Training, which extends the work of Macchiarella et al. (2006), the researchers examine the impact of assimilating simulation training into an ab initio flight training course. They compare the performance and course progression of 29 university student pilots at an Australian flight school (p. 38) to a baseline sample from historical data of 62 students. The study participants complete 13.5 lessons in a Redbird FMX flight simulator $(20 \%-25 \%$ of their private pilot license [PPL] training); students from the baseline sample did not use simulators 
that much (p. 39). Then they complete 13 lessons in a Cessna 172 aircraft to reach the first solo flight, followed by 14 lessons to take the General Flying Progress Test, followed by another 17 additional lessons to obtain their PPL (p. 39). The researchers calculate the difference in training hours during the training course using TERs. There are three recommendations for future research:

1. Investigate effects due to seasonal variations, different flight instructors, and minor alterations to the course structure, and investigate which lessons or training activities to target for simulator training (p. 38).

2. Research the best way to integrate simulation training into an established flighttraining curriculum and how best to address barriers like availability of aircraft, simulators, instructors, and students (p. 44).

3. Conduct further research into how flight schools can correctly implement the findings from relevant transfer research to develop a more effective, proficient, and efficient flight-training program (p. 44).

Full flight simulators and full flight trainers. This section presents the eight transfer studies that employed an FFS or FFT as the lowest level of simulation in the investigation.

Bürki-Cohen and Go (2005). In this quasi-transfer experiment, The Effect of Simulator Motion Cues on Initial Training of Airline Pilots, the researchers summarize the fourth motion study by the FAA/Volpe Center for Simulator Flight Fidelity Requirements Program (p. 1). They compare the flight precision performance and control inputs of two groups. The first group is comprised of 20 commercial pilots with low JAR-25 experience trained on engine-failures during takeoff and manual engine-out landings, both with and without simulating severe weather conditions, in a Thompson Training \& Simulation FFS with 6 DOF. The second group is 
comprised of 20 low-JAR-25-experienced pilots similarly trained in the Mechtronix FFT with a 1 DOF dynamic seat (FFT-X) (pp. 3-6). The conclusions prompt two recommendations:

1. Complete additional multivariate analyses to more fully examine the effect of motion in an ILS approach and provide a better power estimate (p. 11).

2. Examine the training progress of pilots with the consideration of each participant's training and perception (p. 11).

Bürki-Cohen, Sparko, and Go (2007). In this article, Training Value of a Fixed-base Flight Simulator with a Dynamic Seat, the authors (a) define motion and perception cues (pp. 23); (b) compare airplane and simulator motion and simulator motion technology (p. 4); and (c) discuss research on motion fidelity, costs, and needs in airline pilot training (pp. 6-8). They also describe the quasi-transfer experiments from Phases 1 and 2 of the type-rating program for the National Aviation Authorities (NAA) and discuss the research plan for Phase 3 (p. 10). In Phase 2, six NAA pilots (two experienced \& four non-experienced) undergo training in a fixed-base full flight trainer (FFT-1), followed by training in a FFT with a dynamic seat and the FAA Level D FFS data package (FFT-X). The conclusions prompt two recommendations:

1. Investigate whether to base simulation standards on effective stimulation of the pilot or precise simulation of the airplane (p. 17).

2. Investigate the transfer of training effectiveness of an FTD with a simulator cockpit that matches the cockpit in the target aircraft and that employs a realistic operational representation of both national air space and air-traffic-control environment (p. 18).

Casner, Geven, and Williams (2012). In this quasi-transfer experiment, The Effectiveness of Airline Pilot Training for Abnormal Events, the researchers determine whether difficulties in responding to abnormal in-flight events appear in a random sample of airline 
pilots. Using NASA Ames' Level D, B747-400 flight simulator, 18 commercial pilots train on an aerodynamic stall, low-level wind shear, and engine failure on takeoff maneuvers both under the standard procedures used during airline training (control condition) and under unexpected circumstances that might occur during an actual flight (treatment condition) (pp. 478-479). The researchers conclude that while existing simulator training and testing practices facilitate a pilot's ability to respond to abnormal events, such training may not generalize by developing a pilot's ability to recognize such events and perform appropriately during a real flight (p. 483). They offer one recommendation for future research:

1. Investigate the transfer effectiveness of training for a surprise (abnormal) event, turning off the automation, and re-evaluating testing practices.

Svensson, Angelborg-Thanderz, Borgvall, and Castor (2013). This analysis, Skill Decay, Re-Acquisition Training, and Transfer Studies in the Swedish Air Force: A Retrospective Review, the authors examine the military research published in the 1970s and 1980s that focused on either speed of skill decay and re-acquisition training or transfer of training performance in the JA35 Draken single-seat fighter jet and simulator (p. 1). For the simulator study, the researchers designed and developed pilot proficiency tests based on interviews with subject matter experts and selected checklists to provide valid and reliable performance measures of aircraft, radar, and weapon systems operations. The 16 pilot participants had varying experience on the JA35D, having not flown it anytime from 6 months to 12 years (pp. 4-5). They compare these measures to a control group of 35 active JA35D pilots (p. 5). The researchers used structural equation modeling to produce models of causal relationships for the three factors (p. 6). The results show performance ratings significantly lower for the experimental group before training compared to after training but showed no differences between the experimental group 
and the control group after training (p. 8). The participants in the transfer study are six pilots from the simulator study (p. 10). Using a repeated measures design, the researchers measure 78 variables (25 missions per participant) and calculate variance (inter-subject and intra-subject), and the subjects provide self-ratings on mental effort, motivation, and mood (p. 10). The instructors tended to rate the pilots lower in the air compared to training, but pilot ratings were the same as after simulation training (p. 12). For the experimental group, their mental workload decreased after training, but it was significantly higher after the training compared to that of the control group (p. 12). Their efficiency and durability were lower than that of the control group, yet the model showed a significant transfer effect (.40) from simulation to live flight and no significant difference in efficiency factors between simulation training and aircraft performance (p. 13). For skill decay, absence from flying is more important than time in the simulator or aircraft in explaining performance differences (p. 13). The authors provide eight recommendations:

1. Research how best to capture and measure performance in terms of theoretical as well as practical aspects to obtain reliable and valid data (p. 3).

2. Investigate whether the use of the questionnaires alters pilots' decisions, makes them use more and other system functions, and become more analytical in assessing personal performance and mission role (p. 3).

3. Research (model) the extent sets of variables affect each other (measures of the operator and the system), because, as the authors claim, working in terms of causal processes and co-variations between variables is a more powerful scientific procedure than that of classical experimental designs (pp. 15-16). 
4. Research transfer of pilots' use of information systems because it is a mental bottleneck, while flying is over-learned, thus, better retained (p. 17).

5. Investigate the training effectiveness of the timeliness of giving students correct and immediate feedback (p. 17).

6. Investigate transfer retention based on time away from the simulator compared to time on the simulator (p. 18).

7. Research the application of Kolb's experiential learning theory, where trainees train themselves using the tools (e.g., FTDs, simulators) provided in the facility with the support and guidance of instructors (p. 20).

8. Investigate if mastery and resistance against decay for the new skill sets required by today's military pilots will exhibit the same properties as in earlier studies (p. 21).

Pool and Zaal (2015). In this quasi-transfer study, Between-Subject Variability in Transfer-of-Training of Skill-Based Manual Control Behavior, the researchers report on two different experiments investigating transfer effectiveness of reduced motion fidelity on control tasks. They analyze and visualize the between-subject variability of post-transfer performance changes in a pitch control task conducted in the SIMONA Research Simulator by 24 student participants and a roll-control task conducted in the NASA Ames Vertical Motion Simulator by 19 general aviation (GA) pilot participants (p. 1094). There is one recommendation for future research:

1. Conduct a more comprehensive and objective analysis of participant control strategies using the multi-modal pilot modeling techniques as proposed by Pool, Harder, Damveld, van Paassen, and Mulder (2014) and Zaal, Schroeder, and Chung (2015) to gain greater insight into the causes of the changes in error and the control root mean 
square (RMS) of the error signal $e$ defining participants' tracking performance (p. 1098).

Zaal, Schroeder, and Chung (2015). In this quasi-transfer study, Transfer of Training on the Vertical Motion Simulator, 61 GA pilots train on different commercial transport flying tasks under four motion conditions (i.e., no motion, small hexapod, large hexapod, vertical simulator), after which they are tested on the same tasks in a vertical motion simulator motion to find out how different motion conditions affect performance (Abstract). The conclusions prompt one recommendation for future research:

1. Conduct research using objective measures to explore why training with higher motion fidelity yields positive transfer during testing for some tasks but a negative transfer for others (p. 1983).

Pool, Harder, and van Paassen (2016). In this a quasi-transfer experiment, Effects of Simulator Motion Feedback on Training of Skill-Based Control Behavior, the researchers incorporate multimodal human operator modeling techniques to determine how motion feedback from the simulator affects the training of control skills (p. 889). They assess training and skill acquisition in the SIMONA Research Simulator among 24 university students in two experiencematched experimental groups. One group trains with motion feedback before transitioning to the fixed-base condition while the other group trains in the fixed-base condition before transitioning to the moving-base condition (p. 900). The researchers report time, error signals, pitch angle, and control input data for both groups. They provide three recommendations for future research:

1. Investigate the acquisition and retention of manual control skills to quantify simulator-based training effectiveness (p. 900). 
2. Replicate this transfer of training experiment to assess the effects of different factors (e.g., retention and participant experience) on the transfer of skill-based manual control behavior (p. 900).

3. Develop more advanced human-operator modeling techniques for actual flying tasks for use in training effectiveness studies (p. 900).

Landman, van Oorschot, van Paassen, Groen, Bronkhorst, and Mulder (2018). In this quasi-transfer experiment, Training Pilots for Unexpected Events: A Simulator Study on the Advantage of Unpredictable and Variable Scenarios, the researchers investigate improvements in pilot responses to unexpected or unique events when training scenarios incorporate unpredictability and variability (p. 793). They assign 20 pilots to two groups. The treatment group receives unpredictable and variable scenarios, and the control group receives predictable and invariable scenarios. They analyze the flight skill performances of both groups in two posttests that include takeoff, landing, and emergency procedures (one planned and one surprise for each participant) (p. 799). The authors' analyses prompt four recommendations for future research:

1. Conduct further research on the higher interpersonal variation in startle response and alternative interpretations of the startle rating scale (p. 803).

2. Research long-term effects of unpredictable and variable scenario training (p. 803).

3. Research unintended group differences that may have influenced the results (p. 803).

4. Investigate if additional general problem-solving skills exist and whether they transfer to new situations (p. 804). 


\section{Summary of the Findings from the Primary Studies}

The 26 aviation transfer studies investigated the effectiveness of very basic simulation devices to high-fidelity full motion simulators. While the three general classes of flight simulation devices are represented about evenly in this literature, only 10 also investigated transfer to an aircraft. Table 1 presents the studies, the number of participants, research theme, and the general type of simulation devices employed. (See Table B2 for the complete data set.) Table 1

Transfer Studies by Training Devices Used and Number of Participants

\begin{tabular}{|c|c|c|c|c|c|c|}
\hline Studies & $N$ & Research Theme & $\begin{array}{l}\text { BATD / } \\
\text { PCATD }\end{array}$ & $\begin{array}{l}\text { AATD } \\
\text { / FTD }\end{array}$ & $\begin{array}{c}\text { FFS / } \\
\text { FFT }\end{array}$ & $\mathrm{AC}$ \\
\hline Leland et al. (2009) & 51 & abnormal events & $*$ & $*$ & & * \\
\hline McDermott (2005) & 63 & proficiency & * & * & & \\
\hline Nullmeyer et al. (2006) & 22 & proficiency & $*$ & & & * \\
\hline Reweti (2014) & $93^{\mathrm{a}}$ & proficiency & * & $*$ & * & \\
\hline Reweti et al. (2017) & 93 & proficiency & $*$ & * & & \\
\hline Roessingh (2005) & 21 & proficiency & $*$ & & & $*$ \\
\hline Rogers et al. $(2009,2010)$ & 51 & abnormal events & $*$ & & & $*$ \\
\hline Taylor et al. (2004) & 75 & proficiency & $*$ & * & & * \\
\hline Taylor et al. (2005) & 106 & proficiency & * & * & & * \\
\hline Cardullo et al. (2011) & 20 & control & & $*$ & & \\
\hline Sparko et al. (2010) & 40 & motion & & * & * & \\
\hline Nieuwenhuizen et al. (2013) & 9 & motion & & * & * & \\
\hline Mulder et al. (2013) & b & motion & & * & * & \\
\hline McLean et al. (2016) & 91 & proficiency & & $*$ & & $*$ \\
\hline Macchiarella et al. $(2006,2008)$ & $38^{\mathrm{c}}$ & proficiency & & * & & * \\
\hline Koglbauer (2016) & 31 & abnormal events & & $*$ & & \\
\hline Grundy et al. (2016) & 75 & motion & & $*$ & & \\
\hline Donderi et al. (2012) & 54 & control & & $*$ & * & \\
\hline Bürki-Cohen and Go (2005) & 49 & motion & & & * & \\
\hline Bürki-Cohen et al. (2007) & 6 & motion & & & * & * \\
\hline Casner et al. (2012) & 18 & abnormal events & & & * & \\
\hline Landman et al. (2018) & 20 & abnormal events & & & * & \\
\hline Pool et al. (2016) & 24 & motion & & & * & \\
\hline Pool and Zaal (2015) & 24 & control & & & * & \\
\hline Svensson et al. (2013) & $6^{\mathrm{d}}$ & proficiency & & & * & $*$ \\
\hline Zaal et al. (2015) & 61 & motion & & & * & \\
\hline
\end{tabular}

Note. $\mathrm{AC}=$ aircraft. AATD / FTD = advanced aviation training device / flight training device. BATD / PCATD = basic aviation training device / personal computer-based aviation training device. FFS = full flight simulator. FFT = full flight trainer.

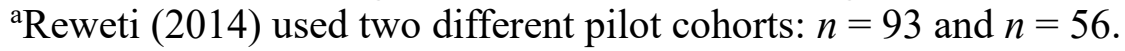

${ }^{b}$ Mulder et al. (2013) did not report a sample size.

${ }^{c}$ Macchiarella et al. $(2006,2008)$ reported 52 participants but only collected data from 38 .

${ }^{d c}$ Svensson et al. (2013) reported 51 participants but only 6 participants in the transfer study. 
The reviewed transfer studies lend support to the claim that simulator training can positively enhance the transfer of training of skills to a live task environment in many contexts. However, findings on the use of simulator motion are mixed.

Research focused on the use of BATDs/PCATDs, AATDs/FTDs, and FFSs/FFTs for training proficiency or abnormal/unexpected events indicated the participants in treatment groups performed significantly better than the participants in the control groups, often with fewer iterations needed to meet performance standards and higher evaluation scores (Leland et al., 2009; Reweti, 2014; Rogers et al., 2009, 2010). When between groups experiments compared simulators of different immersion levels (BATD/PCATD and AATD/FTD), results indicated that there was no difference in performance between treatment groups. Furthermore, all levels of these devices were effective for training purposes, and treatment groups outperformed those in the control groups when training proficiency or abnormal/unexpected events were examined (Koglbauer, 2016; McDermott, 2005; Reweti et al., 2017; Taylor et al., 2004, 2005). In a few studies, the experimental groups achieved the training performance objectives in fewer flight hours and iterations than the control groups (McLean et al., 2016; Macchiarella et al., 2006, 2008).

Between-groups experiments using an FTD reveal that higher fidelity or display resolution may enhance performance and transfer (Cardullo et al., 2011; Donderi et al., 2012). Depending on condition and performance objectives, motion of an FTD or FFS may not significantly impact performance when between groups experiments are conducted (Grundy et al., 2016; Sparko et al., 2010). Research also indicates training in an FFS with motion capability may lead to positive transfer to an aircraft in some but not all conditions (Bürki-Cohen \& Go, 2005; Bürki-Cohen et al., 2007; Svensson et al., 2013; Zaal et al., 2015). Simulator motion 
needs to approximate the cuing stimuli experienced in the real flight environment to enhance transfer and positively affect control behavior (Mulder et al., 2013; Nieuwenhuizen et al., 2013).

Training in an FFS may aid reaction to abnormal and unexpected events, but differences between the treatment and control groups were not statistically significant in some testing conditions (Casner et al., 2012; Landman et al., 2018). It also appears possible that pilot experience can influence the transfer of skills, as well as the degree of skills and behaviors learned, to another environment (Pool et al., 2016; Pool \& Zaal, 2015).

\section{Meta-Analytic and Systematic Reviews of the General Transfer Literature}

This section provides the four seminal meta-analytic and systematic reviews published since 2004 to situate the 26 aviation transfer studies in the broader transfer literature. We include summaries and recommendations for these works as well as an agenda for future research proposed by Ford, Baldwin, and Prasad (2018).

Baldwin, Ford, and Blume (2009). In Transfer of Training 1988-2008: An Updated Review and New Agenda for Future Research (see also Baldwin, Ford, \& Blume, 2017), the authors review 140 journal articles focused on training transfer that cited their original review (Baldwin \& Ford, 1988) to understand the status of transfer research and provide a new research agenda (p. 42). They report transfer researchers are: (a) looking beyond simple motor tasks and examining complete and authentic training contexts, (b) increasing investigation and use of transfer intervention designs, (c) investigating both pretraining and posttraining impacts on transfer, and (d) employing a more extensive assortment of performance measures and numerous time intervals to evaluate transfer (p. 43). There are two recommendations for future research:

1. Develop classes or taxonomies for knowledge, skills, and training contexts to be able to culminate the results of transfer studies across diverse types of training (p. 44). 
2. Investigate whether the motivation to improve work through learning predicts transfer better than assessments of training proficiency and learning motivation (p. 48).

\section{Blume, Ford, Baldwin, and Huang (2010). In Transfer of Training: A Meta-Analytic} Review, the authors examine the reports from 89 empirical works investigating the impacts of predictive factors on training transfer for various tasks and contexts (p. 1065). They report transfer that is measured immediately after a training experience yields consistently stronger relationships with the predictor variables compared to transfer measured after some time lag from the training (p. 1093). They reasonably believe lab studies that incorporate performance measures after a time lag are far superior when compared to studies lacking such measurements, especially in terms of predicting far transfer (p. 1093). Cognitive ability has stronger associations with closed skills, and closed skills encompass considerably more standardized transfer behaviors; consequently, the influence of training environmental context or factors is likely to be significantly less (p. 1093). The authors report that same-source and same measurement-context (SS/SMC) effects - measuring transfer input factors and transfer outcome factors from subjective self-report measures at the same time-inflate relationships to such a degree that interpreting associations becomes exceedingly problematic (pp. 1079-1082).

Consequently, they argue strongly for a moratorium on these types of transfer studies (pp. 10791082). They contend that studies measuring training effectiveness are far superior to studies measuring use (p. 1095). There are seven recommendations for future research:

1. Research the influence of predictors variables (e.g., cognitive ability) on the transfer of open skills for which there is no one correct way to perform as opposed to closed skills for which there is only one right way to behave (p. 1093). 
2. Transfer researchers should "increase precision in their selection and reporting of transfer outcomes" (p. 1094).

3. Research the "effects of different types and forms of transfer measurement" (p. 1095).

4. "Training research could benefit from examining transfer as a conscious choice that individuals make. ... .why is transfer attempted; how are choices made to personalize or customize the training received; why is a choice made not to attempt to transfer an open skill to the field" (p. 1095).

5. Investigate "proactive selection of training cohorts, focus on increasing the motivation of trainees, and finding ways to induce higher levels of supervisor and peer support in the work environment" (p. 1096).

6. Research the "extent that training programs can increase post-training knowledge and self-efficacy to determine the effects on transfer" (p. 1096).

7. Investigate ways of incorporating principles for mitigating relapse throughout training instead of at the end when trainee fatigue occurs (p. 1096).

Wickens, Hutchins, Carolan, and Cumming (2013). In this meta-analysis, Effectiveness of Part-Task Training and Increasing-Difficulty Training Strategies: A MetaAnalysis Approach, the authors assess the transfer effectiveness of part-task training (PTT) and increasing difficulty (ID) strategies designed to decrease intrinsic load per the cognitive load theory (CLT) on various skills from 37 transfer and quasi-transfer military studies published between 1932 and 2009 (pp. 461-462). Their analysis indicates PTT results in negative transfer when the parts are completed simultaneously in the whole transfer tasks but not when completed sequentially, and ID results in positive transfer when increases in difficulty are implemented adaptively and not in fixed steps, which agrees with CLT (p. 468). Another CLT-supported 
finding, which might indicate a new "general principle, is a substantial 'instructor-present cost" (p. 467) characterized by eliminated and slightly reversed benefits of ID strategies and higher mental cost associated with PTT when the instructor is present during training (p. 467). The researchers postulate the "presence and interaction, along with whatever technology used to implement the strategy, may have added extraneous load to the students' task load" [or] "the instructor offered feedback or guidance that was inconsistent with the schedules in the training environment" (pp. 467-468). Conclusions prompt three recommendations:

1. Research the use of adaptive logic for ID simulator training schedules (p. 468).

2. Research the transfer effectiveness of PTT techniques versus variable-priority training (VPT) strategies in learning complex multitask skills and minimizing the number of training trials (p. 468).

3. Research how much experience, skill types, and time-sharing affect transfer (p. 468).

Ford, Baldwin, and Prasad (2018). In this systematic review, Transfer of Training: The Known and the Unknown, the researchers focus on "two key conditions of transfer: the (a) generalization of knowledge, skills, and behaviors learned in training and the (b) maintenance or retention of that learning over a specified period of time" (p. 5.2). They synthesize the reliable knowledge from transfer studies and meta-analyses published since 1988, and "highlight where gaps in knowledge remain acute and where key shifts in our research strategies are warranted" (p. 5.2). Table 2 presents the authors' suggestions for research areas and questions to focus on for future transfer studies. 
Table 2

Research Agenda for Training Transfer

\begin{tabular}{|c|c|c|}
\hline $\begin{array}{l}\text { Future } \\
\text { Agenda }\end{array}$ & Targeted Focus & Research Questions \\
\hline \multirow{2}{*}{$\begin{array}{l}\text { Going one } \\
\text { step beyond: } \\
\text { Greater } \\
\text { precision in } \\
\text { specifying } \\
\text { variables and } \\
\text { interventions }\end{array}$} & $\begin{array}{l}\text { Taking a multidimensional } \\
\text { perspective to workplace } \\
\text { support }\end{array}$ & $\begin{array}{l}\text { Which type of support is needed early in the transfer setting? } \\
\text { What individual differences moderate the impact of support } \\
\text { dimensions on transfer rates? } \\
\text { How do different types of support impact transfer } \\
\text { trajectories? }\end{array}$ \\
\hline & $\begin{array}{l}\text { A renewed emphasis on } \\
\text { interventions to enhance transfer }\end{array}$ & $\begin{array}{l}\text { When and for what type of programs are implementation } \\
\text { intentions more effective? } \\
\text { How effective are after-action reviews around early-transfer } \\
\text { experiences? }\end{array}$ \\
\hline \multirow{2}{*}{$\begin{array}{l}\text { Connecting } \\
\text { the dots: } \\
\text { Emphasis on } \\
\text { transfer as an } \\
\text { episode with } \\
\text { a trajectory } \\
\text { over time }\end{array}$} & $\begin{array}{l}\text { Examining what happens } \\
\text { between acquisition in training } \\
\text { and our measurement of transfer }\end{array}$ & $\begin{array}{l}\text { How does the success/failure of initial applications of trained } \\
\text { material impact transfer trajectories? } \\
\text { What self-regulatory strategies do trainees engage in, and } \\
\text { how do these regulatory strategies impact transfer? }\end{array}$ \\
\hline & $\begin{array}{l}\text { Investigating how individual } \\
\text { skill decay in taskwork and } \\
\text { teamwork skills relates to team } \\
\text { performance? }\end{array}$ & $\begin{array}{l}\text { How do the determinants of maintenance/retention curves } \\
\text { differ at the task and team level? } \\
\text { How does individual skill decay impact team performance? } \\
\text { During a decay period, what unique processes exist at the } \\
\text { team level that may buffer or accelerate decay? }\end{array}$ \\
\hline \multirow{3}{*}{$\begin{array}{l}\text { Shifting the } \\
\text { paradigm: } \\
\text { Emphasis on } \\
\text { contemporary } \\
\text { learning and } \\
\text { authentic } \\
\text { contexts }\end{array}$} & $\begin{array}{l}\text { Research consistent with how } \\
\text { learning is occurring in } \\
\text { organizations today and into the } \\
\text { future }\end{array}$ & $\begin{array}{l}\text { As learning becomes more on-demand, what factors become } \\
\text { more relevant for enhancing transfer? } \\
\text { How can technology be used effectively to enhance the } \\
\text { generalization and maintenance of linked learning events? }\end{array}$ \\
\hline & $\begin{array}{l}\text { Personalization/individualization } \\
\text { of transfer }\end{array}$ & $\begin{array}{l}\text { What novel approaches are suited to capturing individual } \\
\text { training needs? } \\
\text { What factors impact decisions to immediately attempt to } \\
\text { transfer a new knowledge or skill? } \\
\text { How do changes in efficacy, motivation, and learning states } \\
\text { impact transfer trajectories over time? }\end{array}$ \\
\hline & $\begin{array}{l}\text { Taking a problem-centered } \\
\text { approach to the study of transfer }\end{array}$ & $\begin{array}{l}\text { What are effective combinations of pre-, during-, and post- } \\
\text { training interventions? } \\
\text { How does time-to-proficiency criteria align with current } \\
\text { transfer constructs of use and effectiveness? }\end{array}$ \\
\hline
\end{tabular}

Note. Reprinted from "Table 2 Research Agenda for Training Transfer," by J. K. Ford, T. T. Baldwin, and J. Prasad, 2018, Transfer of Training: The Known and the Unknown, p. 5.11. Copyright 2018 by the Annual Review of Organizational Psychology and Organizational Behavior. 


\section{Discussion}

The aim of this descriptive review is to identify the recommendations from the aviation literature reporting fixed-wing simulation experiments with adult subjects that used true transfer or quasi-transfer designs to study transfer outcomes. Among the 26 primary aviation studies published since 2004, there are 16 quasi-transfer studies, 10 true transfer studies, and one incremental transfer study. Ten studies utilize PCATDs, 11 utilize ATDs/FTDs, and 11 utilize FFSs. The following nine aircraft are represented within 10 studies: Aircraft American Champion Super Decathlon, Bellanca Super Decathlon, Beech Bonanza, Beechcraft Sundowner, Lockheed C-130, Cessna-172S, JA35 Draken, Piper Archer III, and an unnamed turboprop. As illustrated in Figure 2, our review of the primary aviation literature revealed four broad research themes, namely training proficiency, motion, abnormal events, and control. Ten studies relate to training proficiency. This category includes five studies on VFR or IFR training (McDermott, 2005; Reweti, 2014; Reweti et al., 2017; Taylor et al., 2004; Taylor et al., 2005); three studies on ab initio pilot training (Macchiarella et al., 2006, 2008; McLean et al., 2016; Roessingh, 2005); one study on CRM training (Nullmeyer et al., 2006); and one study on skill decay and re-acquisition training (Svensson et al., 2013). Eight studies investigate motion (Bürki-Cohen \& Go, 2005; Bürki-Cohen et al., 2007; Grundy et al., 2016; Mulder et al., 2013; Nieuwenhuizen et al., 2013; Pool et al., 2016; Sparko et al., 2010; Zaal et al., 2015). Five studies examine abnormal (unexpected) events (Casner et al., 2012; Koglbauer, 2016; Landman et al., 2018; Leland et al., 2009; Rogers et al., 2009, 2010). Three studies explore control tasks

(Cardullo et al., 2011; Donderi et al., 2012; Pool \& Zaal, 2015). 


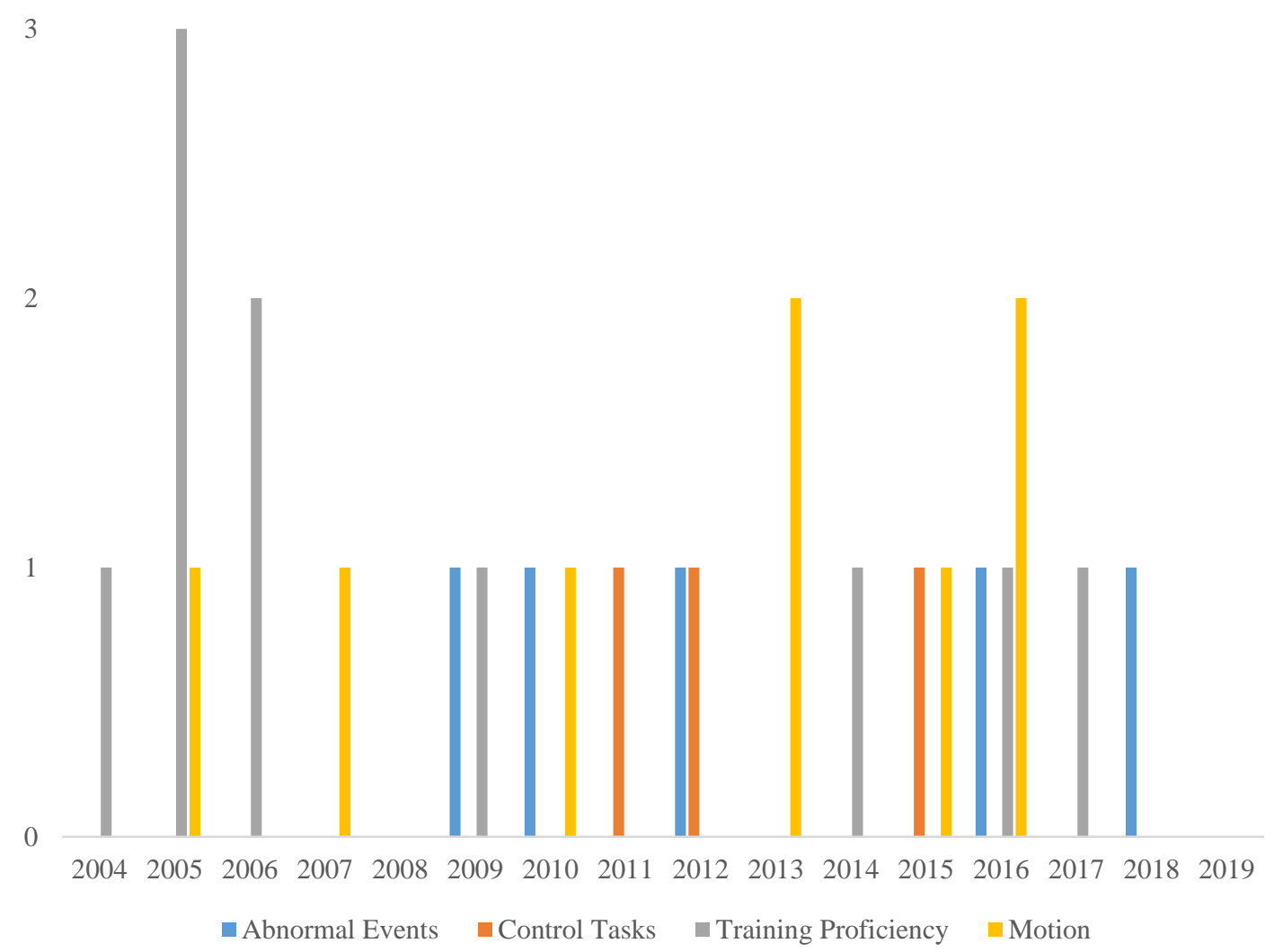

Figure 2. Frequency, publication year, and theme of the flight simulation studies.

Unaddressed topics are potential gaps in the fixed-wing transfer literature. However, this review only encompasses English-language literature published since 2004 and freely available on the Internet and in indexed journals and databases. These delimitations should inform any conclusions and inferences drawn from this study. Nonetheless, this review has significance for researchers, educators, and regulators interested in the effectiveness of flight simulation training.

It appears from the four topic themes (training proficiency, motion, abnormal events, and control tasks) that two key questions remain from these studies. Namely, what type and amount of simulator motion are necessary for positive skill transfer to the aircraft, and what kind and amount of low-fidelity simulation training reduce training time in the airplane? Given the numerous types of simulation devices and configurations, training environments and learning contexts, and knowledge, skills, and abilities required of today's pilots, it is understandable why 
research (and debate) continues in these areas. While there is evidence that the use of validated, low-cost ground-based simulation tools can help mitigate the growing need to train, certify, and type rate more pilots, broad acceptance appears stymied somewhat by pilots' desire to be airborne and regulators' desire for safety.

As stated in the introduction, this review sought to answer this research question: What are the recommendations for future research from the simulation experiments using a true transfer or a quasi-transfer design to study the near or far transfer of airplane flying knowledge, skills, or abilities among adults? We provide the answer in the presentation of 128 research recommendations from the aviation transfer literature published online (51 from the eight metaanalytic and systematic reviews published within the previous 45 years and 66 from the 26 fixedwing studies published within the last 15 years). Table B1 maps the fixed-wing simulation literature to 51 recommendations from the seminal reviews grouped into the broad categories of motion and visual, training performance and proficiency, and methodology improvement. The order of these recommendations does not imply significance nor importance. The first column includes recommendations taken directly from the eight aviation meta-analytic, systematic, and narrative reviews. The second column lists the aviation transfer studies that address the research recommendations either partially or fully. 'None' indicates no transfer studies in our sampling frame mapped to the recommendation, which means the recommendation was not explored using the transfer of training methodology, and it might be a potential research need.

Similarly, potential gaps in the simulation transfer literature may be discovered in Table B1 by the themes and topics that are not addressed. Thirty-three recommendations address training performance and proficiency as the primary theme (Carretta \& Dunlap, 1998; Hays et al., 1992; Jacobs et al., 1990; Rantanen \& Talleur, 2005; Valverde, 1973; Williges et al., 1973). 
Thirteen recommendations address motion and vision (Bürki-Cohen et al., 2011; de Winter et al., 2012a; Hays et al., 1992; Rantanen \& Talleur, 2005; Vaden, 2002; Vaden \& Hall, 2005; Valverde, 1973; Williges et al., 1973). Five recommendations address research methodology improvement (Carretta \& Dunlap, 1998; Hays et al., 1992; Vaden, 2002; Vaden \& Hall, 2005). None of the reviews focused on abnormal events or control tasks; thus, exposing two domain gaps in the synthesis literature. Furthermore, there are 17 recommendations from the seminal meta-analyses without support in the reviewed transfer literature. Virtually all of them are related to training performance and proficiency; thus, exposing additional gaps in this body of literature.

Our review provides the summaries and recommendations in narrative form, and Table B2 presents the data abstracted from the 26 fixed-wing simulation studies. Thus, much of the first part of the process for a meta-analytic review is complete. Therefore, we recommend conducting meta-analyses using the Meta-Analysis Reporting Standards (MARS) of the transfer studies with the appropriate outcome data (comparable samples) to calculate quantitative techniques of effect size estimation and common effects. This recommendation also applies to studies on abnormal events and control tasks. It is also important to mention that non-transfer research undoubtedly addresses some, and possibly many, of the identified recommendations and gaps. Therefore, a logical step would be to extend this narrative review to the broader body of simulation research to highlight additional gaps in the literature and future research opportunities.

Adapting the research agenda by Ford et al. (2018) to our review, Table 3 presents our proposed agenda for future airplane transfer of training research. The three areas under Future Agenda are significant needs, identified in both the aviation and general transfer literature. There is an over-reliance on subjective measures; effect size is largely unreported; there is little 
literature published on far transfer and delayed transfer; the relationship between individual and organizational effectiveness is unexplored. Therefore, we recommend future work on the 11 target areas in Table 3, as these are poignant needs. We also suggest potential research questions for these targets based on this inquiry and additional insight from ERAU flight department personnel (ERAU, 2019). 
Journal of A viation/A erospace Education \& Research, Vol. 29, No. 2 [2020], Art. 5

Table 3

\section{Airplane Simulation Transfer Research Agenda}

\begin{tabular}{|c|c|c|}
\hline $\begin{array}{l}\text { Future } \\
\text { Agenda }\end{array}$ & Target Areas & Potential Research Questions \\
\hline \multirow{3}{*}{$\begin{array}{l}\text { Going One } \\
\text { Step Beyond: } \\
\text { Emphasis on } \\
\text { greater } \\
\text { precision in } \\
\text { specifying } \\
\text { variables and } \\
\text { interventions }\end{array}$} & $\begin{array}{l}\text { Use rigorous methodology and objective measures } \\
\text { for describing changes in participant performance } \\
\text { during simulator training and flight-testing. }\end{array}$ & $\begin{array}{l}\text { What behaviorally anchored pilot- } \\
\text { performance measures reliably predict } \\
\text { skill transfer to the airplane? }\end{array}$ \\
\hline & Collect measures of the operator and system. & $\begin{array}{l}\text { What measures provide the best } \\
\text { discriminatory power in quantifying } \\
\text { differences between FFT-trained and } \\
\text { FFS-trained pilots? }\end{array}$ \\
\hline & $\begin{array}{l}\text { Capture precise, reliable, and valid data and } \\
\text { calculate effect sizes. }\end{array}$ & $\begin{array}{l}\text { What percent of pilot performance } \\
\text { variance is due to simulation training? } \\
\text { Regarding interorganizational validity, } \\
\text { how do the outcomes of ab initio } \\
\text { simulation studies compare to those of } \\
\text { more advanced training? }\end{array}$ \\
\hline \multirow{3}{*}{$\begin{array}{l}\text { Connecting } \\
\text { the Dots: } \\
\text { Emphasis on } \\
\text { near and far } \\
\text { transfer }\end{array}$} & Quantify the permanence of simulation learning. & $\begin{array}{l}\text { What are the effects of the various kinds } \\
\text { and forms of transfer outcomes? } \\
\text { What factors influence change in transfer } \\
\text { trajectories over time? }\end{array}$ \\
\hline & $\begin{array}{l}\text { Develop prediction equations for both near- and far- } \\
\text { learning transfer to inform needed tradeoffs among } \\
\text { main simulation variables to raise the transfer and } \\
\text { retention of specific simulators. }\end{array}$ & $\begin{array}{l}\text { What simulator variables predict near and } \\
\text { far transfer of upset recovery training in } \\
\text { an AATD? }\end{array}$ \\
\hline & $\begin{array}{l}\text { Use empirical data for qualifying features of } \\
\text { BATDs and AATDs. }\end{array}$ & $\begin{array}{l}\text { What parameters are necessary to qualify } \\
\text { BATD and AATD features? }\end{array}$ \\
\hline \multirow{5}{*}{$\begin{array}{l}\text { Shifting the } \\
\text { Paradigm: } \\
\text { Emphasis on } \\
\text { adaptive and } \\
\text { personalized } \\
\text { training in } \\
\text { authentic } \\
\text { contexts }\end{array}$} & $\begin{array}{l}\text { Define ideal pilot performance using normative data } \\
\text { to address bias in check pilot ratings. }\end{array}$ & $\begin{array}{l}\text { What normative data are required in a } \\
\text { task taxonomy to generalize from single } \\
\text { tasks to task groupings? }\end{array}$ \\
\hline & $\begin{array}{l}\text { Leverage the use of computer-assisted adaptive skill } \\
\text { training and performance assessment. }\end{array}$ & $\begin{array}{l}\text { For the automatic adaptation of task } \\
\text { difficulty, should error limits remain } \\
\text { unchanged as skill difficulty and } \\
\text { performance increase, or should they vary } \\
\text { with skill improvement? }\end{array}$ \\
\hline & $\begin{array}{l}\text { Create real-time pilot/flight crew training scenarios } \\
\text { for specific simulation devices, maneuvers, and } \\
\text { various pilot/crew experience and recency levels. }\end{array}$ & $\begin{array}{l}\text { Does integration of the } 3 \text { Component } \\
\text { Model into scenario based Frasca } 172 \\
\text { FTD training improve transfer? }\end{array}$ \\
\hline & $\begin{array}{l}\text { Design the entire flight-simulation training program } \\
\text { to have the best effectiveness at both individual and } \\
\text { organizational levels. }\end{array}$ & $\begin{array}{l}\text { Compared to blocked simulation } \\
\text { instruction, does random or interleaved } \\
\text { training improve flight-time savings? } \\
\text { How does pre-simulation and post- } \\
\text { simulation training interventions impact } \\
\text { transfer outcomes? }\end{array}$ \\
\hline & $\begin{array}{l}\text { Apply experiential learning theory where trainees } \\
\text { train themselves using the simulators provided in } \\
\text { the facility with instructor support and guidance. }\end{array}$ & $\begin{array}{l}\text { Do standardizing flight instructors on the } \\
\text { Frasca } 172 \text { FTD improve student } \\
\text { performance and training transfer? } \\
\text { What types of instructor tasks can } \\
\text { simulators effectively automate? }\end{array}$ \\
\hline
\end{tabular}


As presented in an early comprehensive review of the related research literature, Smode et al. (1966) identified numerous shortcomings in the research literature. Failings included (a) non-comparability of measures across studies, (b) non-comparability of skill levels across pilots, (c) imprecise criterion measurements, (d) over-reliance on subjective measures, (e) non-standard performance tolerance limits, (f) varying interpretations of transfer of training data, and (g) duplicate publications (pp. 9-10). The systematic and meta-analytic reviews of the aviation transfer literature found many of these shortcomings (Bürki-Cohen et al., 2011; Carretta \& Dunlap, 1998; de Winter et al., 2012a, 2012b; Hays et al., 1992; Jacobs et al., 1990; Rantanen \& Talleur, 2005; Vaden, 2002; Vaden \& Hall, 2005; Valverde, 1973; Williges et al., 1973).

Numerous reviewers have provided recommendations to address these shortcomings. To permit generalizability, Valverde (1973) and Williges et al. (1973) recommend developing and using objective measurement techniques. Williges et al. (1973) specifically recommend using scale items that identify if performance tasks are within tolerances and categorical items that identify completion of performance tasks (p. 547). They also recommend researching how instructor ability, variations in the difficulty of the training task, and pilot experience level affect transfer performance (Williges et al., 1973, p. 547). Hays et al. (1992) recommend summarizing the empirical findings as well as the knowledge gaps where future quantitative research studies should focus (p. 51), and also recommend applying rigorous research methodology for all simulator experiments so that the findings do not lead to conflicting explanations for the source of the experimental effects, and report the details of the simulator design/fidelity features (p. 53). For simulator-to-aircraft transfer studies, Carretta and Dunlap (1998) recommend providing appropriate details for the mission requirements and the "research methods (e.g., assignment of participants to control and experimental groups, reasons for loss of participants, methods used to 
estimate interrater agreement), training characteristics (e.g., general training features, instructor variables, student variables, training program), simulator fidelity characteristics” (p. 4). Vaden (2002) recommends using more objective and reliable performance measurements of unsafe tasks because subjective measures, especially self-reports, are either unreliable or do not discriminate well (p. 39). He also recommends using objective performance measurements to quantify the learning curves for specific flight tasks for motion-trained and no-motion-trained pilots (p. 41). de Winter et al. (2012a) recommend measuring changes in pilot performance in the transfer condition when investigating the potential advantages of motion (p. 167).

Although the primary literature we reviewed shows improvement in many of these areas, there remains a few areas of concern that call for caution in interpreting and generalizing their results. For example, only two studies reported effect sizes (Bürki-Cohen \& Go, 2005; Svensson et al., 2013). One study failed to report the number of participants, (Mulder et al., 2013). Several studies had relatively small sample sizes (Nullmeyer et al., 2006; Roessingh, 2005; Cardullo et al., 2011; Nieuwenhuizen et al., 2013; Bürki-Cohen et al., 2007; Casner et al., 2012; Landman et al., 2018; Pool et al., 2016; Pool \& Zaal, 2015; Svensson et al., 2013). Several studies examined subjective self-report measures (Bürki-Cohen et al., 2007; Landman et al., 2018; Nullmeyer et al., 2006; Svensson et al., 2013; Zaal et al., 2015); although a few also collected objective data (i.e., simulator and flight parameters). Obviously, these weaknesses are weaknesses in the literature that could be addressed in future research using improved data collection methods and analyses.

Despite the vast scope of systematic reviews evaluating the primary research literature published over more than 70 years, gaps remain in the contemporary meta-analytic literature. Three of the four analyses published since 2000 focus on the effects of simulator motion (Bürki- 
Cohen et al., 2011; de Winter et al., 2012a, 2012b; Vaden, 2002 [Vaden \& Hall, 2005]). The fourth analysis focuses on the effectiveness of instrument flight training using personal computer-based aviation-training devices [PCATDs] (Rantanen \& Talleur, 2005). The Federal Aviation Administration (FAA) no longer issues approvals for PCATDs; although manufacturers can obtain approval under newer criteria if they meet the appropriate qualifications (FAA AC 61136B, 2018a).

In addition to topics not included in the most recent synthesis literature and the fundamental research issues that continue unaddressed or inadequately addressed, recommendations for investigating many of the problems long identified in pilot training are recurring. We agree with Ford et al. (2018) that transfer researchers need to do a better job of connecting the dots. Conducting more research into far transfer would aid this endeavor, as would an emphasis on translational research that informs actual practice. We also agree that the paradigm needs to shift toward adaptive and personalized training in authentic contexts. One example of how the industry is moving in this direction is SimAssist ${ }^{\mathrm{TM}}$, a software module designed to improve training efficiency in Frasca simulation devices. The software tracks a flight student's proficiency in real-time and provides feedback to the instructor and automatically delivers assistance to the student adapted to his or her current skill proficiency.

Indeed, other advancements and emergent technologies could benefit from transfer research. Despite the application of augmented reality (AR) and virtual reality (VR) technologies in aviation simulation education and training, there is less research focused on their cost, use, and training effectiveness relative to that of flight simulation. Several recommendations touch on these technologies. For example, Carretta and Dunlap (1998) propose linking multiple simulators to create a multi-craft virtual reality environment for 
complex scenario-based, real-time flight training in the military. Macchiarella et al. (2008) and Reweti (2014) propose researching the use of VAT and VATSIM in collegiate flight training curriculums. Reweti (2014) also recommends laying an opaque graphic on the terrain display of the simulator so students can more easily distinguish airspace boundaries. Although this study did not examine the AR/VR literature, to get closer to passing the "Turing Test of simulation" (Hancock, 2009, p. 180), where a computer-generation is indistinguishable from the reality it imitates, we propose researching hybrid simulation by coupling visual and auditory AR/VR simulation with the actual (physical) flight environment. We also recommend inquiries into the potential training effectiveness of "super-simulation" (Hancock, 2009, p. 182) in which AR/VR simulation training provides representations beyond human capabilities. For example, super augmented reality (SAR) and super virtual reality (SVR) training simulations incorporating enhanced visual representations (e.g., infrared and magnification) and enhanced auditory representations (e.g., sound amplification and frequencies above 23,000 Hz).

As mentioned in the introduction, we delimited the primary literature to airplane transfer research published since 2004. We did this because of the large volume of aviation literature and because we wanted to discover what is reliably known about airplane flight simulation training. The average number of airplane-related transfer articles over the last 15 years amounts to less than two per year. We surmise the high cost of FTDs, ATDs, and FFSs, and their constant use for flight training limit their availability for research. Nonetheless, in the absence of more AATDs and FFSs dedicated for research purposes, especially for ab initio pilot training, this issue is going to continue to influence what is reliably known about the effectiveness of flight simulation. 


\section{References}

\section{References marked with an asterisk (*) indicate studies included in a meta-analysis.}

Allerton, D. (2009). Principles of flight simulation. Hoboken, NJ: John Wiley \& Sons. https://doi.org/10.1002/9780470685662

Baldwin, T. T., \& Ford, J. K. (1988). Transfer of training: A review and directions for future research. Personnel Psychology, 41(1), 63-105. https://doi.org/10.1111/j.17446570.1988.tb00632.x

Baldwin, T. T., Ford, J. K., \& Blume, B. D. (2009). Transfer of training 1988-2008: An updated review and agenda for future research. In G. P. Hodgkinson \& J. K. Ford (Eds.), International review of industrial and organizational psychology (Vol. 24, pp. 41-70). John Wiley. https://doi.org/10.1002/9780470745267.ch2

Baldwin, T. T., Ford, J. K., \& Blume, B. D. (2017). The state of transfer of training research: Moving toward more consumer-centric inquiry. Human Resource Development Quarterly, 28(1), 17-28. https://doi.org/10.1002/hrdq.21278

Barnard, J. K. (2005). The effects of a near versus far transfer of training approach on trainees' confidence to coach related and unrelated tasks (Doctoral dissertation, The Ohio State University). Retrieved from ProQuest Dissertations and Theses Global. (Publication No. 3197806)

Blume, B. D., Ford, J. K., Baldwin, T. T., \& Huang, J. L. (2010). Transfer of training: A metaanalytic review. Journal of Management, 36(4), 1065-1105. https://doi.org/10.1177/0149206309352880 
*Bürki-Cohen, J., \& Go, T. H. (2005, August 15-18). The effect of simulator motion cues on initial training of airline pilots [Paper presentation]. Proceedings of the AIAA Modeling and Simulation Technologies Conference and Exhibit (AIAA 2005-6109), San Francisco, CA. https://doi.org/10.2514/6.2005-6109

Bürki-Cohen, J., Sparko, A., \& Bellman, M. (2011, August 8-11). Flight simulator motion literature pertinent to airline-pilot recurrent training and evaluation [Paper presentation]. Proceedings of the AIAA Modeling and Simulation Technologies Conference (AIAA 2011-6320), Portland, OR. https://doi.org/10.2514/6.2011-6320

Bürki-Cohen, J., Sparko, A., \& Go, T. W. (2007, August 20-23). Training value of a fixed-base flight simulator with a dynamic seat [Paper presentation]. Proceedings of the AIAA Modeling and Simulation Technologies Conference and Exhibit (AIAA 2007-6564), Hilton Head, SC. https://doi.org/10.2514/6.2007-6564

Cardullo, F. M., Stanco, A., Kelly, L., Houck, J, \& Grube, R. (2011, August 8-11). A transfer of training study of control loader dynamics [Paper presentation]. Proceedings of the AIAA Modeling and Simulation Technologies Conference, Portland, OR. https://doi.org/10.2514/6.2011-6349

Carretta, T. R., \& Dunlap, R. D. (1998). Transfer of training effectiveness in flight simulation: 1986 to 1997 (AFRL-HE-AZ-TR-1998-0078). United States Air Force Research Laboratory. https://doi.org/10.21236/ada362818

Casner, S. M., Geven, R. W., \& Williams, K. T. (2012). The effectiveness of airline pilot training for abnormal events. Human Factors: The Journal of the Human Factors and Ergonomics Society, 55(3), 477-485. https://doi.org/10.1177/0018720812466893 
Cooper, H. (2010). Research synthesis and meta-analysis: A step-by-step approach (4th ed.). Los Angeles: CA. Sage Publications.

*de Winter, J. C. F., Dodou, D., \& Mulder, M. (2012a). Supplementary material for "Training effectiveness of whole body flight simulator motion: A comprehensive meta-analysis." Retrieved from t.ly/ygnx

*de Winter, J. C. F., Dodou, D., \& Mulder, M. (2012b). Training effectiveness of whole body flight simulator motion: A comprehensive meta-analysis. The International Journal of Aviation Psychology, 22(2), 164-183. https://doi.org/10.1080/10508414.2012.663247

Donderi, D. C., Niall, K. K., Fish, K., \& Goldstein, B. (2012). Above-real-time training (ARTT) improves transfer to a simulated flight control task. Human Factors: The Journal of the Human Factors and Ergonomics Society, 54(3), 469-479. https://doi.org/10.1177/0018720812439711

Embry-Riddle Aeronautical University (ERAU). (2019). Innovation project 2024 (Unpublished Microsoft PowerPoint presentation).

Federal Aviation Administration (FAA). (2018a). Advisory Circular 61-136B, FAA approval of aviation training devices and their use for training and experience. U.S. Department of Transportation. Retrieved from https://www.faa.gov/documentLibrary/media/Advisory_Circular/AC_61-136B.pdf Federal Aviation Administration (FAA). (2018b). Flight Standards Information Management System (FSIMS) Order 8900.1, Volume 11, Chapter 10 §1. U.S. Department of Transportation. Retrieved from http://fsims.faa.gov/wdocs/8900.1/V11\%20AFS\%20Programs/Chapter\%2010/11_010_00 1.htm 
Federal Aviation Administration Flight Simulation Training Device Initial and Continuing Qualification and Use. (2008, May 9). 73 Fed. Reg. 26477 (codified at 14 C.F.R. Pt. 60). Retrieved from https://www.federalregister.gov/d/08-1183

*Feddersen, W. E. (1962). The role of motion information and its contribution to simulation validity (Tech. Rep. No. D228-429-001). Bell Helicopter Company.

Ford, J. K., Baldwin, T. T., \& Prasad, J. (2018, January). Transfer of training: The known and the unknown. Annual Review of Organizational Psychology and Organizational Behavior, 5(1), 201-225. https://doi.org/10.1146/annurev-orgpsych-032117-104443

Ford, J. K., \& Weissbein, D. A. (1997). Transfer of training: An updated review and analysis. Performance Improvement Quarterly, 10(2), 22-41. doi:10.1111/j.19378327.1997.tb00047.x

*Go, T., Bürki-Cohen, J., Chung, W., Schroeder, J., Saillant, G., Jacobs, S., \& Longridge, T. (2003, August 11-14). The effects of enhanced hexapod motion on airline pilot recurrent training and evaluation [Paper presentation]. Proceedings of the AIAA Modeling and Simulation Technologies Conference and Exhibit (AAIA-2003-5678), Austin, TX. https://doi.org/10.2514/6.2003-5678

*Go, T., Bürki-Cohen, J., \& Soja, N. N. (2000, August 14-17). The effect of simulator motion on pilot training and evaluation [Paper presentation]. Proceedings of the AIAA Modeling and Simulation Technologies Conference and Exhibit (AIAA-2000-4296), Denver, CO. https://doi.org/10.2514/6.2000-4296 
Grundy, J. G., Nazar, S., O’Malley, S., Mohrenshildt, M. V., \& Shedden, J. M. (2016). The effectiveness of simulator motion in the transfer of performance on a tracking task is influenced by vision and motion disturbance cues. Human Factors: The Journal of the Human Factors and Ergonomics Society, 58(4), 546-559. https://doi.org/10.1177/0018720816639776

Hancock, P. A. (2009). The future of simulation. In D. A.Vincenzi, J. A.Wise, M. Mouloua, \& P. A. Hancock (Eds.), Human factors in simulation and training (pp. 169-186). Boca Raton, FL: CRC Press/Taylor \& Francis Group. https://ebookcentral-proquestcom.ezproxy.libproxy.db.erau.edu/lib/erau/reader.action?docID $=381355 \& p p g=188$

Hays, R. T., Jacobs, J. W., Prince, C., \& Salas, E. (1992). Flight simulator training effectiveness: A meta-analysis. Military Psychology, 4(2) 63-74. https://doi.org/10.1207/s15327876mp0402_1

International Civil Aviation Organization (ICAO). (2011). Global and regional 20-year forecasts: Pilots, maintenance personnel, air traffic controllers, 9956.

Jacobs, J. W., Prince, C., Hays, R. T., \& Salas, E. (1990). A meta-analysis of the flight simulator training research (Tech. Rep. No. TR-89-006). Naval Training Systems Center. https://apps.dtic.mil/dtic/tr/fulltext/u2/a228733.pdf

Koglbauer, I. (2016). Simulator training improves pilots' procedural memory and generalization of behavior in critical flight situations. Cognition, Brain, Behavior, 20(4), 357-366. Retrieved from https://www.researchgate.net/publication/312173784

Koonce, J. M., \& Bramble, W. J., Jr. (1998). Personal computer-based flight training devices. The International Journal of Aviation Psychology, 8(3), 277-292. https://doi.org/10.1207/s15327108ijap0803_7 
Landman, A., van Oorschot, P., van Paassen, M. M., Groen, E. L., Bronkhorst, A. W., \& Mulder, M. (2018). Training pilots for unexpected events: A simulator study on the advantage of unpredictable and variable scenarios. Human Factors: The Journal of the Human Factors and Ergonomics Society, 60(6), 793-805. https://doi.org/10.1177/0018720818779928

Leland, R., Rogers, R. O., Boquet, A., \& Glaser, S. (2009). An experiment to evaluate transfer of upset-recovery training conducted using two different flight simulation devices (DOT/FAA/AM-09/17). Department of Transportation, Federal Aviation Administration. Retrieved from https://www.academia.edu/32044967

Macchiarella, N. D., Arban, P. K., \& Doherty, S. M. (2006). Transfer of training from flight training devices to flight for ab-initio pilots. International Journal of Applied Aviation Studies, 6(2). Retrieved from https://commons.erau.edu/publication/149

Macchiarella, N. D., Brady, T., \& Lyon, B. S. (2008). An application of high fidelity FTDs for ab initio pilot training: The way ahead. Collegiate Aviation Review International, 26(1), 6575. http://dx.doi.org/10.22488/okstate.18.100367

McDermott, J. T. (2005). A comparison of the effectiveness of a personal computer-based aircraft training device and a flight training device at improving pilot instrument proficiency: A case study in leading regulatory change in aviation education (Doctoral dissertation). Bowling Green State University. ProQuest UMI Number: 3193688

McLean, G. M. T., Lambeth, S., \& Mavin, T. (2016). The use of simulation in ab initio pilot training. The International Journal of Aviation Psychology, 26(1-2), 36-45. https://doi.org/10.1080/10508414.2016.1235364 
Mulder, M., Zaal, P., Pool, D. M., Damveld, H. J., \& van Paassen, M. (2013, August 19-22). A cybernetic approach to assess simulator fidelity: Looking back and looking forward [Paper presentation]. AIAA Modeling and Simulation Technologies (MST) Conference, Boston, MA. https://doi.org/10.2514/6.2013-5225

Nieuwenhuizen, F. M., Mulder, M., van Paassen, M. M., \& Bülthoff, H. H. (2013). Influences of simulator motion system characteristics on pilot control behavior. Journal of Guidance, Control, and Dynamics, 36(3). https://doi.org/10.2514/1.59257

Nullmeyer, R. T., Spiker, V. A., Golas, K. C., Logan, R. C., \& Clemons, L. (2006). The effectiveness of a PC-based C-130 crew resource management aircrew training device (AFRL-HE-AZ-TP-2007-0002). Air Force Research Laboratory Human Effectiveness Directorate Warfighter Readiness Research Division. Retrieved from https://apps.dtic.mil/dtic/tr/fulltext/u2/a467700.pdf

Pool, D. M., Harder, G. A., Damveld, H. J., van Paassen, M. M., \& Mulder, M. (2014, October 5-8). Evaluating simulator-based training of skill-based control behavior using multimodal operator models [Paper presentation]. 2014 IEEE International Conference on Systems, Man, and Cybernetics (SMC), San Diego, CA. https://doi.org/10.1109/smc.2014.6974409

Pool, D. M., Harder, G. A., \& van Paassen, M. M. (2016). Effects of simulator motion feedback on training of skill-based control behavior. Journal of Guidance, Control, and Dynamics, 39(4), 889-901. https://doi.org/10.2514/1.g001603 
Pool, D. M., \& Zaal, P. M. T. (2015, October 9-12). Between-subject variability in transfer-oftraining of skill-based manual control behavior [Paper presentation]. Proceedings of the 2015 IEEE International Conference on Systems, Man, and Cybernetics, Kowloon, China. https://doi.org/10.1109/smc.2015.196

Rantanen, E. M., \& Talleur, D. A. (2005, September 26-30). Incremental transfer and cost effectiveness of groundbased flight trainers in university aviation programs [Paper presentation]. Proceedings of the Human Factors and Ergonomics Society 49th Annual Meeting, Orlando, FL. https://doi.org/10.1177/154193120504900705

Reweti, S. (2014). PC-based aviation training devices for pilot training in visual flight rules procedures; development, validation and effectiveness (Doctoral dissertation). Massey University, Palmerston North, New Zealand. Retrieved from https://mro.massey.ac.nz/bitstream/handle/10179/5454/02_whole.pdf

Reweti, S., Gilbey, A., \& Jeffrey, L. (2017). Efficacy of low-cost pc-based aviation training devices. Journal of Information Technology Education: Research, 16, 127-142. https://doi.org/10.28945/3682

Roessingh, J. J. (2005). Transfer of manual flying skills from pc-based simulation to actual flight-comparison of in-flight measured data and instructor ratings. The International Journal of Aviation Psychology, 15(1), 67-90. https://doi.org/10.1207/s15327108ijap1501_4

Rogers, R. O., Boquet, A., Howell, C., \& DeJohn, C. (2009). An experiment to evaluate transfer of low-cost simulator-based upset-recovery training (DOT/FAA/AM Report No. 09/5). Department of Transportation, Federal Aviation Administration. Retrieved from https://apps.dtic.mil/dtic/tr/fulltext/u2/a500290.pdf 
Rogers, R. O., Boquet, A., Howell, C., \& DeJohn, C. (2010). A two-group experiment to measure simulator-based upset recovery training transfer. International Journal of Applied Aviation Studies, 10(1), 153-168. FAA Academy. Retrieved from https://www.academy.jccbi.gov/ama-800/Summer_2010.pdf

Roscoe, S. N., \& Williges, B. H. (1980). Measurement of transfer of training. In S. N. Roscoe (Ed.), Aviation Psychology (pp. 182-216). Iowa State University Press.

Smode, A. F., Hall, E. R., \& Meyer, D. E. (1966). An assessment of research relevant to pilot training (AMRL-TR-66-196). Aerospace Medical Research Laboratories, Aerospcae Medical Division, Air Force Systems Command. https://doi.org/10.1037/e448542004-001

*Sparko, A. L., Bürki-Cohen, J., \& Go, T. H. (2010, August 2-5). Transfer of training from a fullflight simulator vs. a high-level flight training device with a dynamic seat [Paper presentation]. Proceedings of the AIAA Modeling and Simulation Technologies Conference (Vol. 8218), Toronto, Ontario Canada. https://doi.org/10.2514/6.2010-8218

Svensson, E., Angelborg-Thanderz, M., Borgvall, J., \& Castor, M. (2013). Skill decay, reacquisition training, and transfer studies in the Swedish Air Force: A retrospective review. In W. Arthur, Jr., E. A. Day, W. Bennett, Jr., \& A. M. Portrey (Eds.) (Applied Psychology Series) Individual and Team Skill Decay: The Science and Implications for Practice (pp. 258-281). Retrieved from t.ly/8xdG

Taylor, H. L., Talleur, D. A., Emanuel, T. W., \& Rantanen, E. M. (2005). Transfer of training effectiveness of a flight training device (FTD). International Symposium on Aviation Psychology, 736-740. Retrieved from https://corescholar.libraries.wright.edu/isap_2005/132 
Taylor, H. L., Talleur, D. A., Rantanen, E. M., \& Emanuel, T. W., Jr. (2004). The effectiveness of a personal computer aviation training device, a flight training device, and an airplane in conducting instrument proficiency checks. Volume 1: Subjective Pilot Performance Evaluation. Final Technical Report AHFD-04-12/FAA-04-5. Federal Aviation Administration Civil Aerospace Medical Institute, Oklahoma City, OK. Retrieved from http://www.tc.faa.gov/logistics/grants/pdf/2001/01-G-037\%20Volume\%201.pdf

Vaden, E. A. (2002, Fall). The effect of simulator platform motion on pilot training transfer: A meta-analysis. Embry-Riddle Aeronautical University Scholarly Commons - Theses (203). Retrieved from https://commons.erau.edu/db-theses/203

*Vaden, E. A., \& Hall, S. (2005). The effect of simulator platform motion on pilot training transfer: A meta-analysis. The International Journal of Aviation Psychology, 15(4), 375393. https://doi.org/10.1207/s15327108ijap1504_5

Valverde, H. H. (1968). Flight simulators: A review of research and development (Tech. Rep. No. AMRL-TR-68-97). Wright Patterson Air Force Base, Aerospace Medical Research Laboratory.

Valverde, H. H. (1973). A review of flight simulator transfer of training studies. Human Factors: The Journal of the Human Factors and Ergonomics Society, 15(6), 510-522. https://doi.org/10.1177/001872087301500603

*van der Pal, J. (1999). The effect of simulator motion on parameter training for F-16 pilots. Engineering Psychology and Cognitive Ergonomics: Vol. 3. Transportation Systems, Medical Ergonomics and Training. In E. Harris (Ed.), Proceedings of the 1st International Conference on Engineering Psychology and Cognitive Ergonomics (pp. 267-275). Ashgate. https://doi.org/10.1201/9780429027918-33 
Wickens, C. D., Hutchins, S., Carolan, T., \& Cumming, J. (2013). Effectiveness of part-task training and increasing-difficulty training strategies: A meta-analysis approach. Human Factors: The Journal of the Human Factors and Ergonomics Society, 55(2), 461-470. https://doi.org/10.1177/0018720812451994

Williges, B. H., Roscoe, S. N., \& Williges, R. C. (1973). Synthetic flight training revisited. Human Factors, 15(6), 543-560. https://doi.org/10.1177/001872087301500606

Zaal, P. M., Schroeder, J. A., \& Chung, W. W. (2015). Transfer of training on the vertical motion simulator. Journal of Aircraft, 52(6), 1971-1984. https://doi.org/10.2514/6.2014-2206 


\section{Appendix A}

\section{List of Definitions}

AATD: An advanced aviation training device: "1. Meets or exceeds the criteria outlined in Appendix B. 2. Meets or exceeds the criteria outlined in Appendix C, Advanced Aviation Training Device (AATD) Requirements. 3. Provides an adequate training platform for both procedural and operational performance tasks specific to the ground and flight training requirements for Private Pilot Certificate, instrument rating, Commercial Pilot Certificate, and Airline Transport Pilot (ATP) Certificate, and Flight Instructor Certificate per Parts 61 and 141. Provides an adequate platform and design for both procedural and operational performance tasks required for instrument experience, the instrument proficiency check (IPC), and pilot time. 5. The FAA finds acceptable in a manner described in this AC." (FAA AC 61-136B, 2018a, p. A1).

ATD: $\quad$ An aviation training device "is a training device, other than a full flight simulator (FFS) or flight training device (FTD), that has been evaluated, qualified, and approved by the Administrator as a basic or advanced ATD (refer to 14 CFR part 61, § 61.1). In general, this includes a replica of aircraft instruments, equipment, panels, and controls in an open flight deck area or an enclosed aircraft cockpit. It includes the hardware and software necessary to represent a category and class of aircraft (or set of aircraft) operations in ground and flight conditions having the appropriate range of capabilities and systems installed in the device as described within this AC for the specific basic or advanced qualification level. . . . 3. Provides an adequate training platform for both procedural and operational performance tasks specific to the ground and flight training requirements for Private Pilot Certificate, Instrument Rating, Commercial Pilot Certificate, and Airline Transport Pilot (ATP) Certificate, and Flight Instructor Certificate per Parts 61 and 141. 4. Provides an adequate platform and design for both procedural and operational performance tasks required for instrument experience, the instrument proficiency check (IPC), and pilot time." (FAA AC 61-136B, 2018a, pp. A-1-A-2).

BATD: A basic aviation training device: "1. Meets or exceeds the criteria outlined in Appendix B, Basic Aviation Training Device (BATD) Requirements. 2. Provides an adequate training platform and design for both procedural and operational performance tasks specific to the ground and flight training requirements for Private Pilot Certificate and instrument rating per 14 CFR parts 61 and 141. 3. Provides an adequate platform for both procedural and operational performance tasks required for instrument experience and pilot time. 4. The FAA finds acceptable in a manner described in this AC." (FAA AC 61-136B, 2018a, p. A-1). 
Cumulative Total amount of time to train to a performance criterion.

Transfer:

Delayed Performance learned via simulation training that is evaluated in the

Transfer: $\quad$ operational setting some length of time after the conclusion of the training.

Far Transfer: The extent to which the trainee applies what was learned in training to situations that are different or new from those in which they were trained (Barnard, 2005, p. 9).

FFS: $\quad$ A full flight simulator is "a replica of a specific type, make, model, or series aircraft. It includes the equipment and computer programs necessary to represent aircraft operations in ground and flight conditions, a visual system providing an out-of-the-flight deck view, a system that provides cues at least equivalent to those of a three-degree-of-freedom motion system, and has the full range of capabilities of the systems installed in the device as described in part 60 of this chapter and the QPS for a specific FFS qualification level." (Federal Aviation Administration Flight Simulation Training Device Initial and Continuing Qualification and Use, 73 Fed. Reg. 26477, § 60.3, 2008).

FSTD: $\quad$ A flight simulation training device is "a full flight simulator (FFS) or a flight training device (FTD)" (FAA Flight Simulation Training Device Initial and Continuing Qualification and Use, 73 Fed. Reg. 26477, § 60.3, 2008).

FTD: A flight training device is "a replica of aircraft instruments, equipment, panels, and controls in an open flight deck area or an enclosed aircraft flight deck replica. It includes the equipment and computer programs necessary to represent aircraft (or set of aircraft) operations in ground and flight conditions having the full range of capabilities of the systems installed in the device as described in part 60 of this chapter and the qualification performance standard (QPS) for a specific FTD qualification level.” (FAA Flight Simulation Training Device Initial and Continuing Qualification and Use, 73 Fed. Reg. 26477, § 60.3, 2008).

Incremental Number of sessions to train to a performance criterion.

Transfer:

Near

Transfer:

The extent to which a trainee applies what was learned in training to situations that are similar to those in which they were trained (Barnard, 2005, p. 8).

Negative Knowledge, skills, or abilities acquired via simulation training (stimulus

Transfer: condition) applied incorrectly in the target setting (operational condition) or interfere with the learning acquisition of other KSAs.

PCATD: $\quad$ A personal computer-based aviation-training device designed to simulate specific aircraft systems and aid the learning development of related knowledge and procedural skills. The FAA no longer issues approvals for PCATDs, but manufacturers can obtain a BATD or AATD approval if they meet the appropriate FAA qualifications (FAA AC 61-136B, 2018a). 
Positive Usually determined by whether the training time for an experimental group is Transfer reduced, relative to a control group, in the aircraft regardless of how much time that group spent in the simulator.

Transfer Typically measured as the amount of time for an experimental group to reach Effectiveness: a specific performance criterion in the aircraft relative to a control group (Allerton, 2009; Roscoe \& Williges, 1980).

Transfer of The degree to which a trainee applies the knowledge, skills, and abilities Training: (KSAs) required for performance of the training task to performance of that task in the real world (Baldwin \& Ford, 1988; Ford, Baldwin, \& Prasad, 2018; Ford \& Weissbein, 1997). 


\section{Appendix B}

\section{Table B1}

Tables

\section{Primary Aviation Transfer Studies Mapped to the Recommendations from the Seminal Aviation Reviews}

\begin{tabular}{|c|c|}
\hline Motion and Vision Related Recommendations & Primary Aviation Studies \\
\hline $\begin{array}{l}\text { 1. Conduct additional motion research to examine the relationship between the transfer and fidelity of } \\
\text { simulated motion cues to determine what types and amounts of motion are essential for flight training tasks } \\
\text { (Williges et al., 1973, p. 547; Valverde, 1973, p. 519). }\end{array}$ & $\begin{array}{l}\text { Bürki-Cohen \& Go (2005); Bürki-Cohen et al. (2007); Grundy } \\
\text { et al. (2016); Mulder et al. (2013); Nieuwenhuizen et al. } \\
\text { (2013); Pool et al. (2016); Sparko et al. (2010); Zaal et al. } \\
\text { (2015) }\end{array}$ \\
\hline $\begin{array}{l}\text { 2. Investigate what motion characteristics pilots perceive and how acceleration thresholds fluctuate under } \\
\text { stress conditions (Williges et al., 1973, p. 550). }\end{array}$ & $\begin{array}{l}\text { Bürki-Cohen \& Go (2005); Grundy et al. (2016); Mulder et al. } \\
\text { (2013); Nieuwenhuizen et al. (2013); Pool et al. (2016); Sparko } \\
\text { et al. (2010); Zaal et al. (2015) }\end{array}$ \\
\hline $\begin{array}{l}\text { 3. Research the relationship between pilot workload in the cockpit and the significance of motion cues for } \\
\text { different levels of participant flight experience (Williges et al., 1973, p. 545). }\end{array}$ & $\begin{array}{l}\text { Bürki-Cohen \& Go (2005); Grundy et al. (2016); Mulder et al. } \\
\text { (2013); Nieuwenhuizen et al. (2013); Pool et al. (2016); Sparko } \\
\text { et al. (2010); Zaal et al. (2015) }\end{array}$ \\
\hline $\begin{array}{l}\text { 4. Examine the benefit of extracockpit visual simulation in developing perceptual responses during flight } \\
\text { without the aid of associated psychomotor reactions (Williges et al., 1973, p. 545). }\end{array}$ & none \\
\hline $\begin{array}{l}\text { 5. Conduct research to explain the importance of contact displays both as part of and not part of the specific } \\
\text { simulator employed and the value of presenting cues for vision and motion at the same time (Williges et al., } \\
\text { 1973, p. 546). }\end{array}$ & $\begin{array}{l}\text { Macchiarella et al. (2006); Macchiarella et al. (2008); Donderi } \\
\text { et al. (2012); Reweti (2014); Grundy et al. (2016); Reweti et al. } \\
\text { (2017) }\end{array}$ \\
\hline $\begin{array}{l}\text { 6. Research whether prior cognizance of motion cues, cue redundancy from visual motion cues or instrument } \\
\text { feedback, the sort of task trained, and relative lack of sensitivity in the performance tools used to measure } \\
\text { differences between pilots trained with and without simulator motion diminishes transfer of training (Vaden, } \\
2002, \text { p. 44; Vaden \& Hall, 2005, p. 398). }\end{array}$ & none \\
\hline $\begin{array}{l}\text { 7. Use objective performance measurements to quantify the learning curves for specific flight tasks for } \\
\text { motion-trained and no-motion-trained pilots (Vaden, 2002, p. 41; Vaden \& Hall, 2005, p. 391). }\end{array}$ & Pool \& Zaal (2015); Pool et al. (2016); Roessingh (2005) \\
\hline $\begin{array}{l}\text { 8. Research new motion chair devices to determine if they can provide some or even all of the training } \\
\text { benefits that full-motion platforms currently offer at a fraction of the price (Vaden \& Hall, 2005, p. 389). }\end{array}$ & Bürki-Cohen et al. (2007); Sparko et al. (2010) \\
\hline $\begin{array}{l}\text { 9. Research if motion cues elicit pilot disturbance control strategies comparable to the strategies used in an } \\
\text { aircraft to gain a better understanding of the roles of the visual and vestibular sensory systems in isolated } \\
\text { pitch-tracking tasks and other control tasks (Bürki-Cohen et al., 2011, p. 8). }\end{array}$ & $\begin{array}{l}\text { Bürki-Cohen \& Go (2005); Grundy et al. (2016); Mulder et al. } \\
\text { (2013); Nieuwenhuizen et al. (2013); Pool et al. (2016); Sparko } \\
\text { et al. (2010) }\end{array}$ \\
\hline
\end{tabular}




\section{Table B1}

\section{Primary Aviation Transfer Studies Mapped to the Recommendations from the Seminal Aviation Reviews Continued}

\begin{tabular}{|c|c|}
\hline Motion and Vision Related Recommendations Continued & Primary Aviation Studies \\
\hline $\begin{array}{l}\text { 10. When investigating the potential advantages of motion, measure changes in pilot performance in the } \\
\text { transfer condition (de Winter et al., 2012a, p. 167). }\end{array}$ & $\begin{array}{l}\text { Bürki-Cohen \& Go (2005); Bürki-Cohen et al. (2007); Grundy et } \\
\text { al. (2016); Mulder et al. (2013); Nieuwenhuizen et al. (2013); } \\
\text { Pool et al. (2016); Sparko et al. (2010); Zaal et al. (2015) }\end{array}$ \\
\hline $\begin{array}{l}\text { 11. Conduct further research to determine the visual cueing requirements for low-level flight (Hays et al., } \\
\text { 1992, p. 53). }\end{array}$ & Reweti (2014) \\
\hline $\begin{array}{l}\text { 12. Conduct research with more modern simulators that have a basic visual system to investigate the nature } \\
\text { and effectiveness of additional cues to be learned (Rantanen \& Talleur, 2005, p. 767). }\end{array}$ & $\begin{array}{l}\text { Bürki-Cohen \& Go (2005); Grundy et al. (2016); Mulder et al. } \\
\text { (2013) }\end{array}$ \\
\hline $\begin{array}{l}\text { 13. Research the merits of using simulator motion for training experts in manual-control disturbance tasks (de } \\
\text { Winter et al., 2012a, p. 176). }\end{array}$ & $\begin{array}{l}\text { Bürki-Cohen \& Go (2005); Bürki-Cohen et al. (2007); Cardullo } \\
\text { et al. (2011); Grundy et al. (2016); Mulder et al. (2013); } \\
\text { Nieuwenhuizen et al. (2013); Pool et al. (2016); Sparko et al. } \\
\text { (2010); Zaal et al. (2015) }\end{array}$ \\
\hline Performance and Proficiency Related Recommendations & Primary Aviation Studies \\
\hline $\begin{array}{l}\text { 1. Investigate whether time-sharing skills learned in an inexpensive training device transfer to the aircraft and } \\
\text { if they are retained over time (Williges et al., 1973, p. 546). }\end{array}$ & $\begin{array}{l}\text { Leland et al. (2009); Macchiarella et al. (2006); Macchiarella et } \\
\text { al. (2008); McLean et al. (2016); Nullmeyer et al. (2006); } \\
\text { Roessingh (2005); Rogers et al. (2009, 2010); Taylor et al. } \\
\text { (2004) }\end{array}$ \\
\hline $\begin{array}{l}\text { 2. Research the level of pilot experience on open-loop [i.e., skills relying on subconscious control that does } \\
\text { not use or reference feedback] training for closed-loop tasks [i.e., skills requiring conscious reference to } \\
\text { feedback, called perceptual trace] (Williges et al., 1973, p. 546). }\end{array}$ & none \\
\hline $\begin{array}{l}\text { 3. Conduct research to learn what constitutes ideal pilot performance using normative data to address bias in } \\
\text { check pilot ratings (Williges et al., 1973, p. 548). }\end{array}$ & none \\
\hline 4. Research the permanence of simulator learning vis-à-vis far transfer (Williges et al., 1973, p. 549). & $\begin{array}{l}\text { Macchiarella et al. (2006); Macchiarella et al. (2008); Taylor et } \\
\text { al. (2004, 2005); Svensson et al. (2013) }\end{array}$ \\
\hline $\begin{array}{l}\text { 5. Research the use of ground-based or aerial trainers to identify residual attention tasks that are useful as a } \\
\text { quick and reliable means of measuring initial learning proficiency in routine pilot training, certification, and } \\
\text { recurrency checks, similar to the research in human engineering experiments (Williges et al., 1973, p. 553). }\end{array}$ & none \\
\hline $\begin{array}{l}\text { 6. With regards to automatic adaptation, conduct research to learn if error limits should remain unchanged as } \\
\text { skill performance improves and the task gets more complicated or if error limits should vary with } \\
\text { improvement in participant's performance (Williges et al., 1973, p. 552). }\end{array}$ & none \\
\hline $\begin{array}{l}\text { 7. Research the types of flight operations and pilot tasks forecasted for the future to derive minimum skill, } \\
\text { knowledge, and decision-making standards required for all classifications of pilots flying in the U.S. (Williges et } \\
\text { al., 1973, p. 556). }\end{array}$ & none \\
\hline $\begin{array}{l}\text { 8. Develop new pilot training, certification, and recency assurance systems (e.g., computer-assisted adaptive } \\
\text { skill training and performance assessment) capable of automatically qualifying pilots for their particular level } \\
\text { of operation at an affordable cost to pilots and the aviation community (Williges et al., 1973, p. 556). }\end{array}$ & none \\
\hline
\end{tabular}




\section{Table B1}

\section{Primary Aviation Transfer Studies Mapped to the Recommendations from the Seminal Aviation Reviews Continued}

Performance and Proficiency Related Recommendations Continued

9. To validate a simulator task classification system, report detailed training outcome information for individual tasks (Hays et al., 1992,
p. 51).

10. To validate an aviation task classification system, determine the simulator instructional features that lead to positive transfer and training outcomes for specific aviation tasks (Hays et al., 1992, p. 52).

11. Research, develop, and validate aviation task categories (taxonomies) to be able to generalize the results of single-task performance to groups of tasks and thereby avoid expensive duplication of future research efforts (Hays et al., 1992, p. 51).

12. Develop convenient ways of measuring a learner's cognitive and non-cognitive capabilities because of cognitive ability influencing training outcomes (Hays et al., 1992, p. 52).

13. Research the improvement of student motivation and acceptance of simulator training (Hays et al., 1992, p. 45).

14. Determine the effects on training outcomes for each source of knowledge of results (KOR) (printout from the simulator device or verbal debrief by the instructor) or the combined use of different sources of KOR (Hays et al., 1992, p. 44).

15. Research the effects of the timing and the amount of information in KOR sources on training transfer (Hays et al., 1992, p. 44). 16. Given the goal of devising blocked training programs that are equally effective as programs using proficiency-based criteria, research the impact of accompanying instructional features (e.g., backward chaining procedure) in a training program that will show the relevant learning principles and methods (Hays et al., 1992, p. 53)

17. The ability to link multiple simulators to form a virtual multi-craft environment that enables pilots to fly near real-time mission simulations necessitates research into the acquisition of complex skills and group performance in multi-craft training scenarios

(Carretta \& Dunlap, 1998, p. 4).

18. Perform a training-course analysis to identify which maneuvers are most effectively trained using a simulator to maximize the average flight-time savings across all flight students in the training program (Rantanen \& Talleur, 2005, p. 767).

19. Investigate standardizing instructors on the use of the simulator and proficiency on the maneuvers they will teach (Rantanen \& Talleur, 2005, p. 767).

20. Research the effectiveness of training emergency procedures in PCATDs (Rantanen \& Talleur, 2005, p. 767).

21. Investigate if it is more effective to train maneuvers in piecemeal in a simulator before integrating them into training in the aircraft than it is to teach and learn in a simulator just like a pilot fly the airplane (Rantanen \& Talleur, 2005, p. 768).

22. Investigate part-task training and what methods instructors can employ to teach the basics of aircraft control and procedures out of the context of specific maneuvers, because of students with poor control skills and procedural knowledge struggle learning to perform complex flight maneuvers (Rantanen \& Talleur, 2005, p. 768).

23. Investigate the comparative value of part-task trainers and whole-task trainers to enable the use of less expensive trainers when appropriate (Williges et al., 1973, p. 546).
Primary Aviation Studies

Cardullo et al. (2011); Casner et al.

(2012); McLean et al. (2016);

Mulder et al. (2013);

Nieuwenhuizen et al. (2013)

none

none

none

none

none

none

none

none

Macchiarella et al. (2006)

Macchiarella et al. (2008)

none

Leland et al. (2009); Rogers et al. (2009, 2010)

none

none

none 


\section{Table B1}

\section{Primary Aviation Transfer Studies Mapped to the Recommendations from the Seminal Aviation Reviews Continued}

\begin{tabular}{|c|c|}
\hline Performance and Proficiency Related Recommendations Continued & Primary Aviation Studies \\
\hline $\begin{array}{l}\text { 24. Research what is the optimum size [and instructional sequence (Valverde, 1973, p. 521)] for each learning chunk in simulator } \\
\text { training (Williges et al., 1973, p. 546) }\end{array}$ & none \\
\hline $\begin{array}{l}\text { 25. To validate a simulator task classification system, report detailed training outcome information for individual tasks (Hays et al., } \\
\text { 1992, p. 51). }\end{array}$ & $\begin{array}{l}\text { Bürki-Cohen et al. (2007); Cardullo } \\
\text { et al. (2011); Casner et al. (2012); } \\
\text { McLean et al. (2016); Mulder et al. } \\
\text { (2013); Nieuwenhuizen et al. (2013) }\end{array}$ \\
\hline $\begin{array}{l}\text { 26. Investigate the degree that procedural flight tasks and emergency management situation tasks trained in a PCATD transfer to the } \\
\text { airplane (Rantanen \& Talleur, 2005, p. 767). }\end{array}$ & $\begin{array}{l}\text { Leland et al. (2009); Rogers et al. } \\
(2009,2010)\end{array}$ \\
\hline $\begin{array}{l}\text { 27. Use Response Surface Methodology (RSM) to investigate many variables simultaneously and develop prediction equations that } \\
\text { model learning in the simulator, training transfer to the aircraft, and maintenance over time that can be used to compare indispensable } \\
\text { tradeoffs in vital simulation variables to maximize the transfer effectiveness and retention of specific simulators (Williges et al., 1973, p. } \\
556 \text { ). }\end{array}$ & none \\
\hline $\begin{array}{l}\text { 28. Systematically investigate the use of PCATDs for practicing emergency procedures and part-task training and whether scenario- } \\
\text { based flight training increases transfer effectiveness by imposing the associations of tasks that students would typically learn or practice } \\
\text { separately (Rantanen \& Talleur, 2005, p. 768). }\end{array}$ & $\begin{array}{l}\text { Leland et al. (2009); Rogers et al. } \\
(2009,2010)\end{array}$ \\
\hline $\begin{array}{l}\text { 29. Investigate the application of line-oriented flight training (LOFT) in the general aviation population (Rantanen \& Talleur, 2005, p. } \\
\text { 768). }\end{array}$ & none \\
\hline $\begin{array}{l}\text { 30. Research more objective and reliable performance measurements of unsafe tasks because subjective measures, especially self- } \\
\text { reports, are either unreliable or do not discriminate well (Vaden, 2002, p. 39; Vaden \& Hall, 2005, p. 389). }\end{array}$ & Casner et al. (2012) \\
\hline $\begin{array}{l}\text { 31. Investigate how the instructional design of the training program, as opposed to just individual training simulation devices, impacts } \\
\text { transfer effectiveness (Bürki-Cohen et al., 2011, p. 15). }\end{array}$ & $\begin{array}{l}\text { Macchiarella et al. (2006); } \\
\text { Macchiarella et al. (2008); } \\
\text { McDermott (2005); McLean et al. } \\
\text { (2016); Reweti et al. (2014, 2017); } \\
\text { Taylor et al. (2004) }\end{array}$ \\
\hline $\begin{array}{l}\text { 32. Conduct further research on the transfer of skills acquired in the simulator to the airplane and if and how independent effects of } \\
\text { pilot experience and task type affect skill transfer (de Winter et al., 2012a, p. 179). }\end{array}$ & none \\
\hline $\begin{array}{l}\text { 33. To permit generalizability, develop adequate measurement techniques (objective measures: scale items that identify if performance } \\
\text { tasks are within tolerances and categorical items that identify completion of performance tasks) and research how instructor ability, } \\
\text { variations in the difficulty of the training task, and pilot experience level affect transfer performance (Williges et al., 1973, p. 547; }\end{array}$ & none \\
\hline Valverde, 1973, pp. 520-521). & \\
\hline
\end{tabular}




\section{Table B1}

Primary Aviation Transfer Studies Mapped to the Recommendations from the Seminal Aviation Reviews Continued

\begin{tabular}{|c|c|}
\hline Methodology Improvement Related Recommendations & Primary Aviation Studies \\
\hline $\begin{array}{l}\text { 1. For quantitative literature reviews, summarize the empirical findings as well as the knowledge gaps where future research studies } \\
\text { should focus (Hays et al., 1992, p. 51). }\end{array}$ & $n / a$ \\
\hline $\begin{array}{l}\text { 2. For all simulator experiments, apply rigorous research methodology so that the findings do not lead to conflicting explanations for } \\
\text { the source of the experimental effects, and report the details of the simulator design/fidelity features (Hays et al., 1992, p. 53). }\end{array}$ & $\begin{array}{l}\text { Leland et al. (2009); Macchiarella et } \\
\text { al. (2006); Macchiarella et al. } \\
\text { (2008); McLean et al. (2016); } \\
\text { Nullmeyer et al. (2006); Rogers et } \\
\text { al. (2009, 2010); Svensson et al. } \\
\text { (2013); Taylor et al. (2004) }\end{array}$ \\
\hline $\begin{array}{l}\text { 3. When conducting simulator-to-aircraft transfer studies, provide appropriate details for the mission requirements and the "research } \\
\text { methods (e.g., assignment of participants to control and experimental groups, reasons for loss of participants, methods used to } \\
\text { estimate interrater agreement), training characteristics (e.g., general training features, instructor variables, student variables, training } \\
\text { program), simulator fidelity characteristics" (Carretta \& Dunlap, 1998, p. 4). }\end{array}$ & $\begin{array}{l}\text { Leland et al. (2009); Macchiarella et } \\
\text { al. (2006); Macchiarella et al. } \\
\text { (2008); McLean et al. (2016); } \\
\text { Nullmeyer et al. (2006); Rogers et } \\
\text { al. (2009, 2010); Roessingh (2005); } \\
\text { Svensson et al. (2013); Taylor et al. } \\
\text { (2004, 2005) }\end{array}$ \\
\hline $\begin{array}{l}\text { 4. Determine which assessment scenarios permit the most accurate performance measurements to be able to evaluate the value of the } \\
\text { estimated effect size for motion (Vaden, 2002, p. 44; Vaden \& Hall, 2005, p. 389). }\end{array}$ & $\begin{array}{l}\text { Bürki-Cohen \& Go (2005); Svensson } \\
\text { et al. (2013) }\end{array}$ \\
\hline $\begin{array}{l}\text { 5. Given the prevalent use of subjective instructor/pilot ratings, improve subjective performance measures by documenting inter-rater } \\
\text { reliability in experiments (Hays et al., 1992, p. 54). }\end{array}$ & $\begin{array}{l}\text { Bürki-Cohen \& Go (2005); Koglbauer } \\
\text { (2016); Landman et al. (2018); } \\
\text { Macchiarella et al. (2006); } \\
\text { Macchiarella et al. (2008); } \\
\text { Nullmeyer et al. (2006); Svensson et } \\
\text { al. (2013); Taylor et al. (2004) }\end{array}$ \\
\hline
\end{tabular}

Note. $\mathrm{n} / \mathrm{a}=$ not applicable. 


\section{Table B2}

Abstracted Data from 26 Airplane Transfer Studies

\begin{tabular}{|c|c|c|c|c|c|c|c|c|c|c|c|c|c|c|c|c|c|}
\hline $\begin{array}{c}\text { Authors } \\
\text { (Year) }\end{array}$ & Title & Theme & Type & Research Design & Participants & $s$ Experience & $\begin{array}{c}\text { Skills } \\
\text { Assessed }\end{array}$ & $\begin{array}{l}\text { BATD / } \\
\text { PCATD }\end{array}$ & $\begin{array}{c}\text { AATD / } \\
\text { FTD }\end{array}$ & FFS & Aircraft & $\begin{array}{c}\text { Independent } \\
\text { Variables }\end{array}$ & $\begin{array}{l}\text { Dependent } \\
\text { Measures }\end{array}$ & $\begin{array}{c}\text { Data } \\
\text { Collection }\end{array}$ & Analysis & $\begin{array}{c}\text { Effect } \\
\text { Size }\end{array}$ & $\begin{array}{l}\text { Chief } \\
\text { Results }\end{array}$ \\
\hline $\begin{array}{l}\text { Bürki- } \\
\text { Cohen \& } \\
\text { Go (2005) } \\
\\
\end{array}$ & $\begin{array}{l}\text { "The } \\
\text { Effect of } \\
\text { Simulator } \\
\text { Motion } \\
\text { Cues on } \\
\text { Initial } \\
\text { Training of } \\
\text { Airline } \\
\text { Pilots" }\end{array}$ & $\begin{array}{l}\text { motion } \\
f\end{array}$ & 更 & $\begin{array}{l}\text { matched-pairs } \\
\text { design testing } \\
\text { two factors: one } \\
\text { between } \\
\text { subjects and one } \\
\text { within-subjects, } \\
\text { and each factor } \\
\text { with two fixed } \\
\text { levels }\end{array}$ & $\begin{array}{l}4 \text { airline } \\
\text { pilots } \\
\\
\end{array}$ & $\begin{array}{l}\text { new hires, } \\
\text { pre- } \\
\text { simulator } \\
\text { training, } \\
\text { experience } \\
\text { range of } \\
<3000 \text { hours } \\
\text { in twin- } \\
\text { engine } \\
\text { turboprops } \\
\text { to } 17000 \\
\text { hours in jets }\end{array}$ & $\begin{array}{l}\text { V1 Cut } \\
\text { (engine 2 } \\
\text { failed on } \\
\text { takeoff) and } \\
\text { ILS Approach } \\
\text { (engine 2 } \\
\text { rsfailed) } \\
\end{array}$ & & & $\begin{array}{l}\text { CAE FFS, } \\
\text { Boeing 717- } \\
200 \\
\text { configuration }\end{array}$ & & $\begin{array}{l}\text { motion } \\
\text { condition } \\
\text { (two levels) }\end{array}$ & $\begin{array}{l}\sim 80 \text { control- } \\
\text { input and } \\
\text { performance } \\
\text { variables; pilot } \\
\text { questionnaires }\end{array}$ & $\begin{array}{l}\text { recorded } \\
\text { simulator } \\
\text { parameters, } \\
\text { surveys }\end{array}$ & $\begin{array}{l}\text { two-by-two } \\
\text { mixed ANOVA }\end{array}$ & $\begin{aligned} & \text { yes } s \\
& \text { s } \\
& \text { s } \\
& e \\
& \text { it } \\
& 1 \\
& a \\
& c \\
& g \\
& b \\
& \text { t } \\
& \text { e }\end{aligned}$ & $\begin{array}{l}\text { Small but } \\
\text { statistically } \\
\text { significant alerting } \\
\text { effect of motion for } \\
\text { initial training. } \\
\text { Motion positively } \\
\text { affected airspeed } \\
\text { control. No-motion } \\
\text { group maintained } \\
\text { better pedal control } \\
\text { than the } \\
\text { experimental group. }\end{array}$ \\
\hline $\begin{array}{l}\text { Bürki- } \\
\text { Cohen et } \\
\text { al. (2007) } \\
\\
\end{array}$ & $\begin{array}{l}\text { "Training } \\
\text { Value of a } \\
\text { Fixed-base } \\
\text { Flight } \\
\text { Simulator } \\
\text { with a } \\
\text { Dynamic } \\
\text { Seat" }\end{array}$ & motion & QT & $\begin{array}{l}\text { Phases } 1 \& 2 \\
\text { quasi-transfer } \\
\text { experiments: } \\
\text { Phase 1: Proof of } \\
\text { concept. Phase } \\
\text { 2: Proof of } \\
\text { concept and } \\
\text { testbed } \\
\text { collection of } \\
\text { objective data. } \\
\text { Phase } 3 \text { : } \\
\text { Transfer } \\
\text { experiment } \\
\text { using a } 2 \times 2 \times 3 \\
\text { factorial design. }\end{array}$ & $\begin{array}{l}6 \text { pilots; } \\
\text { National } \\
\text { Aviation } \\
\text { fAuthorities } \\
\text { (NAA) } \\
\text { employees } \\
\end{array}$ & $\begin{array}{l}\text { single type } \\
\text { rating } \\
<6000 \mathrm{hrs} \text {. } \\
\text { to multiple } \\
\text { type ratings } \\
\text { w/airlines } \\
>11000 \mathrm{hrs} \text {. }\end{array}$ & $\begin{array}{l}\text { type-rating } \\
\text { maneuvers to } \\
\text { mastery and } \\
\text { within } \\
\text { s allowable } \\
\text { limits (flight } \\
\text { preparation, } \\
\text { takeoff, flight } \\
\text { maneuvers, } \\
\text { and } \\
\text { procedures, } \\
\text { missed } \\
\text { approach } \\
\text { landing) }\end{array}$ & & & $\begin{array}{l}\text { FFT-1 and the } \\
\text { FFT-X Level D } \\
\text { simulators; } \\
\text { 48-passenger } \\
\text { airplane with } \\
\text { two wing- } \\
\text { mounted } \\
\text { turboprop } \\
\text { engines }\end{array}$ & $\begin{array}{l}\text { unnamed } \\
\text { turboprop }\end{array}$ & $\begin{array}{l}\text { training } \\
\text { platform; } \\
\text { training } \\
\text { regime; data } \\
\text { collection } \\
\text { period }\end{array}$ & $\begin{array}{l}\text { Subjective } \\
\text { opinions } \\
\text { (evaluators, } \\
\text { instructors, } \\
\text { and trainees); } \\
\text { recordings } \\
\text { from the } \\
\text { training }\end{array}$ & $\begin{array}{l}\text { Phase 1: } \\
\text { questionnaires, } \\
\text { instructor } \\
\text { assessment, } \\
\text { debrief (no } \\
\text { data recorded } \\
\text { from the } \\
\text { simulator or } \\
\text { airplane). } \\
\text { Phases } 2 \& \text { 3: } \\
\text { simulator \& } \\
\text { aircraft data } \\
\text { collected. }\end{array}$ & design & $\begin{array}{ll}\text { no } & \mathrm{T} \\
\mathrm{t} \\
\mathrm{t} \\
\mathrm{s} \\
\mathrm{p} \\
\mathrm{c} \\
\mathrm{T} \\
\mathrm{g}\end{array}$ & $\begin{array}{l}\text { Transfer from FFTs } \\
\text { to the aircraft was } \\
\text { satisfactory, and all } \\
\text { performance } \\
\text { criteria were met. } \\
\text { The transfer was } \\
\text { generally positive. }\end{array}$ \\
\hline $\begin{array}{l}\text { Cardullo } \\
\text { et al. } \\
\text { (2011) }\end{array}$ & $\begin{array}{l}\text { "A } \\
\text { Transfer } \\
\text { of Training } \\
\text { Study of } \\
\text { Control } \\
\text { Loader } \\
\text { Dynamics" }\end{array}$ & $\begin{array}{l}\text { control } \\
\text { tasks } \\
g\end{array}$ & QT & $\begin{array}{l}\text { between groups } \\
\text { experiment }\end{array}$ & $\begin{array}{l}20 \\
\text { participants } \\
\text { (10 per } \\
\text { group) }\end{array}$ & $\begin{array}{l}\text { not } \\
\text { described }\end{array}$ & $\begin{array}{l}\text { maintaining } \\
\text { straight and } \\
\text { level flight } \\
\text { during a } \\
\text { disturbance }\end{array}$ & & $\begin{array}{l}\text { Generic } \\
\text { Flight } \\
\text { Deck } \\
\text { (GFD) } \\
\text { simulator }\end{array}$ & & & $\begin{array}{l}\text { fidelity level } \\
\text { (high or low) }\end{array}$ & $\begin{array}{l}\text { transfer; } \\
\text { asymptotic } \\
\text { tracking error }\end{array}$ & $\begin{array}{l}\text { Recorded } \\
\text { simulator } \\
\text { parameters; } \\
\text { calculated } \\
\text { parameters }\end{array}$ & $\begin{array}{l}\text { RMS tracking } \\
\text { error and RMS } \\
\text { running } \\
\text { cumulative } \\
\text { average } \\
\text { analyses; intend } \\
\text { to perform } \\
\text { power spectral } \\
\text { density analysis }\end{array}$ & no & $\begin{array}{l}\text { Low fidelity group } \\
\text { had poorer } \\
\text { performance and } \\
\text { low transfer rates. }\end{array}$ \\
\hline
\end{tabular}

Note. AATD / FTD = advanced aviation training device / flight training device. BATD / PCATD = basic aviation training device / personal computer-based aviation training device. FFS $=$ full flight simulator. FFT $=$ full flight trainer. ILS = instrument landing system. RMS $=$ root mean square. QT $=$ quasi-transfer. $\mathrm{T}=$ transfer. 


\section{Table B2 Continued}

\section{Abstracted Data from 26 Airplane Transfer Studies}

\begin{tabular}{|c|c|c|c|c|c|c|c|c|c|c|c|c|c|c|c|c|c|}
\hline Authors (Year) & Title & Theme & Type & $\begin{array}{l}\text { Research } \\
\text { Design }\end{array}$ & Participants & Experience & $\begin{array}{c}\text { Skills } \\
\text { Assessed }\end{array}$ & $\begin{array}{l}\text { BATD / } \\
\text { PCATD }\end{array}$ & $\begin{array}{l}\text { AATD / } \\
\text { FTD }\end{array}$ & $\begin{array}{l}\text { FFS / } \\
\text { FFT }\end{array}$ & Aircraft & $\begin{array}{c}\text { Independent } \\
\text { Variables }\end{array}$ & $\begin{array}{c}\text { Dependent } \\
\text { Measures }\end{array}$ & $\begin{array}{c}\text { Data } \\
\text { Collection } \\
\end{array}$ & Analysis & $\begin{array}{c}\text { Effect } \\
\text { Size }\end{array}$ & 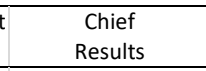 \\
\hline $\begin{array}{l}\text { Casner et al. } \\
\text { (2012) }\end{array}$ & $\begin{array}{l}\text { "The } \\
\text { Effectiveness } \\
\text { of Airline } \\
\text { Pilot Training } \\
\text { for Abnormal } \\
\text { Events" }\end{array}$ & $\begin{array}{l}\text { abnormal / } \\
\text { unexpected } \\
\text { events }\end{array}$ & QT & $\begin{array}{l}\text { within- } \\
\text { subjects } \\
\text { experiment }\end{array}$ & $\begin{array}{l}18 \text { airline } \\
\text { pilots }\end{array}$ & $\begin{array}{l}\text { active } \\
\text { Boeing } 747- \\
400 \text { pilots, } 9 \\
\text { captains, } \\
\text { and } 9 \text { first } \\
\text { officers; } \\
\text { flight hours } \\
\text { ranged from } \\
5000-20000\end{array}$ & $\begin{array}{l}\text { ability to } \\
\text { maintain } \\
\text { control or } \\
\text { abort in an } \\
\text { unexpected } \\
\text { aerodynamic } \\
\text { stall, low- } \\
\text { level wind } \\
\text { shear, and } \\
\text { engine failure } \\
\text { on takeoff } \\
\text { after V1 cut }\end{array}$ & & & $\begin{array}{l}\text { Boeing } \\
747- \\
400 \\
\text { (Level } \\
\text { D) }\end{array}$ & & $\begin{array}{l}\text { abnormal } \\
\text { conditions } \\
\text { presentation (two } \\
\text { levels) }\end{array}$ & $\begin{array}{l}\text { time to respond } \\
\text { to the stall by } \\
\text { applying } \\
\text { maximum } \\
\text { power; } \\
\text { performance in } \\
\text { low-level wind } \\
\text { shear events } \\
\text { (four measures); } \\
\text { performance } \\
\text { engine failure } \\
\text { event (two } \\
\text { measures) }\end{array}$ & $\begin{array}{l}\text { recorded } \\
\text { simulator } \\
\text { parameters; } \\
\text { voice } \\
\text { recordings } \\
\end{array}$ & $\begin{array}{l}\text { stall: } \\
\text { descriptive, } \\
\text {; repeated } \\
\text { measures } \\
\text { ANOVA and } \\
\text { post hoc, } \\
\text { correlations. } \\
\text { LLWS: } \\
\text { descriptive, } \\
\text { paired } t \text {-tests, } \\
\text { correlations. } \\
\text { Engine failure: } \\
\text { descriptive }\end{array}$ & no & $\begin{array}{l}\text { Training aids } \\
\text { response during } \\
\text { routine issues (as } \\
\text { learned in training } \\
\text { sessions), but } \\
\text { responses to } \\
\text { abnormal events } \\
\text { varied. }\end{array}$ \\
\hline $\begin{array}{l}\text { Donderi et al. } \\
\text { (2012) }\end{array}$ & $\begin{array}{l}\text { "Above-Real- } \\
\text { Time Training } \\
\text { (ARTT) } \\
\text { Improves } \\
\text { Transfer to a } \\
\text { Simulated } \\
\text { Flight Control } \\
\text { Task" }\end{array}$ & $\begin{array}{l}\text { control } \\
\text { tasks }\end{array}$ & QT & $\begin{array}{l}\text { mixed- } \\
\text { methods } \\
\text { approach } \\
\text { using } \\
\text { within- } \\
\text { subjects } \\
\text { design and } \\
\text { between- } \\
\text { subjects } \\
\text { experiment }\end{array}$ & $\begin{array}{l}54 \\
\text { university } \\
\text { students } \\
\text { (graduates } \\
\text { and } \\
\text { undergradu } \\
\text { ates) and } \\
\text { technicians }\end{array}$ & $\begin{array}{l}\text { no flight } \\
\text { experience } \\
\text { required }\end{array}$ & $\begin{array}{l}\text { flight } \\
\text { maneuvers } \\
\text { associated } \\
\text { with chase } \\
\text { and capture; } \\
\text { visual-motor } \\
\text { coordination }\end{array}$ & & $\begin{array}{l}\text { F-18A } \\
\text { model } \\
\text { ATD with } \\
\text { controls, } \\
\text { ARTT } \\
\text { equipped }\end{array}$ & $\begin{array}{l}\text { Boeing } \\
747- \\
400 \\
\text { (Level } \\
\text { D) }\end{array}$ & & $\begin{array}{l}\text { screen resolution } \\
\text { (low, medium, or } \\
\text { high); training } \\
\text { speed varied } \\
\text { factorially (slow, } \\
\text { criterion, fast) } \\
\text { across two } \\
\text { sessions, within } \\
\text { participants }\end{array}$ & $\begin{array}{l}\text { time and } \\
\text { distance } \\
\text { performance } \\
\text { measures } \\
\text { between the } \\
\text { target and chase } \\
\text { aircraft; total } \\
\text { time to } \\
\text { complete each } \\
\text { trial }\end{array}$ & $\begin{array}{l}\text { recorded } \\
\text { simulator } \\
\text { parameters }\end{array}$ & $\begin{array}{l}\text { correlations, } \\
\text { MANCOVAs }\end{array}$ & no & $\begin{array}{l}\text { ARTT improves } \\
\text { transfer; high- and } \\
\text { medium-resolution } \\
\text { displays enhance } \\
\text { training for specific } \\
\text { scenarios. }\end{array}$ \\
\hline $\begin{array}{l}\text { Grundy et al. } \\
\text { (2016) }\end{array}$ & $\begin{array}{l}\text { "The } \\
\text { Effectiveness } \\
\text { of Simulator } \\
\text { Motion in the } \\
\text { Transfer of } \\
\text { Performance } \\
\text { on a Tracking } \\
\text { Task Is } \\
\text { Influenced by } \\
\text { Vision and } \\
\text { Motion } \\
\text { Disturbance } \\
\text { Cues" }\end{array}$ & motion & QT & $\begin{array}{l}\text { between } \\
\text { groups } \\
\text { experiment }\end{array}$ & $\begin{array}{l}75 \\
\text { university } \\
\text { students }\end{array}$ & $\begin{array}{l}\text { no flight } \\
\text { experience } \\
\text { required }\end{array}$ & $\begin{array}{l}\text { flight } \\
\text { performance } \\
\text { for a tracking } \\
\text { task }\end{array}$ & & $\begin{array}{l}\text { Moog, Inc. } \\
\text { Stewart } \\
\text { platform } \\
\text { with 6-dof } \\
\text { motion }\end{array}$ & & & $\begin{array}{l}\text { training platform } \\
\text { (5 levels) }\end{array}$ & $\begin{array}{l}\text { performance } \\
\text { measures of } \\
\text { accuracy, track } \\
\text { time, error } \\
\text { integral, and } \\
\text { joystick control }\end{array}$ & $\begin{array}{l}\text { recorded } \\
\text { simulator } \\
\text { parameters }\end{array}$ & $\begin{array}{l}\text { mixed-model } \\
\text { ANOVA that } \\
\text { crosses the } \\
\text { five-factors } \\
\text { between- } \\
\text { subject } \\
\text { variable } \\
\text { training } \\
\text { condition with } \\
\text { the four-factor } \\
\text { within-subject } \\
\text { variable block }\end{array}$ & no & $\begin{array}{l}\text { No significant effect } \\
\text { of motion on } \\
\text { performance. } \\
\text { Disturbance cueing } \\
\text { affects behavior. }\end{array}$ \\
\hline
\end{tabular}

Note. AATD / FTD = advanced aviation training device / flight training device. BATD / PCATD = basic aviation training device / personal computer-based aviation training device. FFS = full flight simulator. FFT = full flight trainer. ILS = instrument landing system. IT = incremental transfer. QT = quasi-transfer. 


\section{Table B2 Continued}

Abstracted Data from 26 Airplane Transfer Studies

\begin{tabular}{|c|c|c|c|c|c|c|c|c|c|c|c|c|c|c|c|c|c|}
\hline $\begin{array}{l}\text { Authors } \\
\text { (Year) }\end{array}$ & Title & Theme & Type & $\begin{array}{l}\text { Research } \\
\text { Design }\end{array}$ & Participants & Experience & $\begin{array}{c}\text { Skills } \\
\text { Assessed }\end{array}$ & $\begin{array}{l}\text { BATD / } \\
\text { PCATD }\end{array}$ & AATD / FTD & FFS / FFT & Aircraft & $\begin{array}{c}\text { Independent } \\
\text { Variables }\end{array}$ & $\begin{array}{c}\begin{array}{c}\text { Dependent } \\
\text { Measures }\end{array} \\
\end{array}$ & $\begin{array}{c}\text { Data } \\
\text { Collection }\end{array}$ & Analysis & $\begin{array}{c}\text { Effect } \\
\text { Size }\end{array}$ & $\begin{array}{c}\begin{array}{c}\text { Chief } \\
\text { Results }\end{array} \\
\end{array}$ \\
\hline $\begin{array}{l}\text { Koglbauer } \\
\text { (2016) }\end{array}$ & $\begin{array}{l}\text { "Simulator } \\
\text { Training } \\
\text { Improves } \\
\text { Pilots' } \\
\text { Procedural } \\
\text { Memory and } \\
\text { Generalization } \\
\text { of Behavior in } \\
\text { Critical Flight } \\
\text { Situations" }\end{array}$ & $\begin{array}{l}\text { abnormal / } \\
\text { unexpected } \\
\text { events }\end{array}$ & QT & $\begin{array}{l}\text { between } \\
\text { groups } \\
\text { experiment }\end{array}$ & 31 pilots & $\begin{array}{l}\text { experience } \\
<450 \text { flight } \\
\text { hours, no } \\
\text { aerobatic } \\
\text { experience }\end{array}$ & $\begin{array}{l}\text { procedural } \\
\text { memory and } \\
\text { behavior in a } \\
\text { new situation }\end{array}$ & & $\begin{array}{l}\text { generic fixed } \\
\text { base, light } \\
\text { aerobatic } \\
\text { aircraft FTD }\end{array}$ & & & $\begin{array}{l}\text { training } \\
\text { platform (two } \\
\text { levels) }\end{array}$ & $\begin{array}{l}\text { performance, } \\
\text { otask } \\
\text { completion } \\
\text { time }\end{array}$ & $\begin{array}{l}\text { instructor } \\
\text { scores } \\
\text { (subjective), } \\
\text { task } \\
\text { completion } \\
\text { time }\end{array}$ & $\begin{array}{l}\text { ANOVA, } \\
\text { Pearson's } \\
\text { correlation }\end{array}$ & 更 & $\begin{array}{l}\text { Training group } \\
\text { recovered } \\
\text { significantly } \\
\text { better \& faster } \\
\text { than control. } \\
\text { Simulator } \\
\text { training } \\
\text { improves } \\
\text { procedural } \\
\text { memory via } \\
\text { iterative } \\
\text { practice. }\end{array}$ \\
\hline $\begin{array}{l}\text { Landman et } \\
\text { al. (2018) }\end{array}$ & $\begin{array}{l}\text { "Training Pilots } \\
\text { for } \\
\text { Unexpected } \\
\text { Events: A } \\
\text { Simulator } \\
\text { Study on the } \\
\text { Advantage of } \\
\text { Unpredictable } \\
\text { and Variable } \\
\text { Scenarios" }\end{array}$ & $\begin{array}{l}\text { abnormal / } \\
\text { unexpected } \\
\text { events }\end{array}$ & QT & $\begin{array}{l}\text { between } \\
\text { groups } \\
\text { experiment }\end{array}$ & $\begin{array}{l}20 \text { airline } \\
\text { pilots }\end{array}$ & $\begin{array}{l}\text { most with } \\
>25 \text { hrs. in } \\
\text { light multi- } \\
\text { engine } \\
\text { aircraft }\end{array}$ & $\begin{array}{l}\text { responses to } \\
\text { unexpected } \\
\text { or novel } \\
\text { events }\end{array}$ & & & SIMONA & & $\begin{array}{l}\text { prediction } \\
\text { and } \\
\text { variability of } \\
\text { failures (two } \\
\text { levels) }\end{array}$ & $\begin{array}{l}\text { performance, } \\
\text { call-out times, } \\
\text { reported } \\
\text { understanding } \\
\text { (subjective), } \\
\text { reported } \\
\text { surprise } \\
\text { (subjective), } \\
\text { startle, manual } \\
\text { skills }\end{array}$ & $\begin{array}{l}\text { recorded } \\
\text { simulator } \\
\text { parameters } \\
\text {, survey, } \\
\text { observation } \\
\end{array}$ & $\begin{array}{l}\text { independent } \\
\text { samples } t- \\
\text { tests, } \\
\text { Pearson's } \\
\text { chi-square } \\
\text { tests, mixed } \\
\text { model } \\
\text { ANOVAs }\end{array}$ & 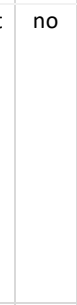 & $\begin{array}{l}\text { No significant } \\
\text { differences } \\
\text { between } \\
\text { groups in } \\
\text { testing, but } \\
\text { the training } \\
\text { group } \\
\text { performed } \\
\text { better during } \\
\text { the posttest. }\end{array}$ \\
\hline $\begin{array}{l}\text { Leland et al. } \\
\text { (2009) }\end{array}$ & $\begin{array}{l}\text { "An } \\
\text { Experiment to } \\
\text { Evaluate } \\
\text { Transfer of } \\
\text { Upset- } \\
\text { Recovery } \\
\text { Training } \\
\text { Conducted } \\
\text { Using Two } \\
\text { Different Flight } \\
\text { Simulation } \\
\text { Devices" }\end{array}$ & $\begin{array}{l}\text { abnormal / } \\
\text { unexpected } \\
\text { events }\end{array}$ & $\mathrm{TT}$ & $\begin{array}{l}3 \times 4 \\
\text { repeated } \\
\text { measures } \\
\text { factorial } \\
\text { experiment }\end{array}$ & 51 pilots & $\begin{array}{l}\text { IFR PPL no } \\
\text { aerobatic } \\
\text { or upset- } \\
\text { recovery } \\
\text { training }\end{array}$ & $\begin{array}{l}\text { upset } \\
\text { recovery }\end{array}$ & $\begin{array}{l}\text { MS Flight } \\
\text { Simulator } \\
2002 \\
\text { desktop } \\
\text { software }\end{array}$ & $\begin{array}{l}\text { Environmental } \\
\text { Tectonics' } \\
\text { GL2000 }\end{array}$ & & $\begin{array}{l}\text { Beech } \\
\text { Bonanza } \\
\text { \& Super } \\
\text { Decathlon } \\
\text { aerobatic } \\
\text { trainer }\end{array}$ & $\begin{array}{l}\text { training } \\
\text { platform } \\
\text { (three } \\
\text { levels); upset } \\
\text { attitude }\end{array}$ & $\begin{array}{l}\text { altitude loss, } \\
\text { maximum G- } \\
\text { force in dive } \\
\text { pullout, } \\
\text { minimum G- } \\
\text { force } \\
\text { unloading in } \\
\text { rolls, response } \\
\text { times }\end{array}$ & $\begin{array}{l}\text { recorded } \\
\text { simulator } \\
\text { parameters }\end{array}$ & $\begin{array}{l}\text { MANOVA, } \\
\text { pairwise } t- \\
\text { tests, ANOVA }\end{array}$ & no & $\begin{array}{l}\text { Treatment } \\
\text { groups } \\
\text { outperformed } \\
\text { the control } \\
\text { group and no } \\
\text { significant } \\
\text { difference } \\
\text { between } \\
\text { treatment } \\
\text { groups. }\end{array}$ \\
\hline $\begin{array}{l}\text { Macchiarella } \\
\text { et al. (2006); } \\
\text { Macchiarella } \\
\text { et al. (2008) }\end{array}$ & $\begin{array}{l}\text { "Transfer of } \\
\text { Training from } \\
\text { Flight Training } \\
\text { Devices to } \\
\text { Flight for Ab- } \\
\text { Initio Pilots" }\end{array}$ & $\begin{array}{l}\text { training } \\
\text { proficiency }\end{array}$ & $\mathrm{TT}$ & $\begin{array}{l}\text { between } \\
\text { groups } \\
\text { experiment }\end{array}$ & $\begin{array}{l}52 \text { total, } 38 \\
\text { used for } \\
\text { data } \\
\text { collection }\end{array}$ & $\begin{array}{l}\text { ab initio } \\
\text { flight } \\
\text { students }\end{array}$ & $\begin{array}{l}34 \text { practical } \\
\text { test } \\
\text { standards } \\
\text { performance } \\
\text { skills }\end{array}$ & & $\begin{array}{l}\text { Frasca } 172 \text { (L6) } \\
\text { FTD }\end{array}$ & & $\begin{array}{l}\text { Cessna } \\
172 S\end{array}$ & $\begin{array}{l}\text { training } \\
\text { platform } \\
\text { (two levels) }\end{array}$ & $\begin{array}{l}34 \\
\text { performance } \\
\text { tasks }\end{array}$ & $\begin{array}{l}\text { instructor } \\
\text { scores }\end{array}$ & $\begin{array}{l}\text { TER, } \\
\text { MANOVA }\end{array}$ & no & $\begin{array}{l}\text { Positive } \\
\text { transfer of } 33 \\
\text { of } 34 \text { tasks; } \\
\text { treatment } \\
\text { group met PTS } \\
\text { standards in } \\
\text { with sig. fewer } \\
\text { iterations for } \\
18 \text { of } 34 \text { tasks. }\end{array}$ \\
\hline
\end{tabular}

Note. AATD / FTD = advanced aviation training device / flight training device. BATD / PCATD $=$ basic aviation training device / personal computer-based aviation training device. dof $=$ degrees of freedom. $F F S=$ full flight simulator. $F F T=$ full flight trainer. $I F R=$ instrument flight rules. IT $=$ incremental transfer. $\mathrm{PPL}=$ private pilot license. $\mathrm{QT}=$ quasi-transfer. Sig. $=$ significant. $\mathrm{T}=$ transfer. $\mathrm{TER}=$ transfer effectiveness ratio. $\mathrm{TT}=$ true transfer. 
Table B2 Continued

Abstracted Data from 26 Airplane Transfer Studies

\begin{tabular}{|c|c|c|c|c|c|c|c|c|c|c|c|c|c|c|c|c|c|}
\hline $\begin{array}{l}\text { Authors } \\
\text { (Year) }\end{array}$ & Title & Theme & Type & $\begin{array}{l}\text { Research } \\
\text { Design }\end{array}$ & Participants & Experience & $\begin{array}{c}\text { Skills } \\
\text { Assessed }\end{array}$ & $\begin{array}{l}\text { BATD / } \\
\text { PCATD } \\
\end{array}$ & $\begin{array}{l}\text { AATD / } \\
\text { FTD } \\
\end{array}$ & FFS / FFT & Aircraft & $\begin{array}{l}\text { Independent } \\
\text { Variables }\end{array}$ & $\begin{array}{l}\text { Dependent } \\
\text { Measures }\end{array}$ & $\begin{array}{c}\text { Data } \\
\text { Collection }\end{array}$ & Analysis & $\begin{array}{c}\text { Effect } \\
\text { Size }\end{array}$ & $\begin{array}{c}\text { Chief } \\
\text { Results }\end{array}$ \\
\hline $\begin{array}{l}\text { McDermott } \\
\text { (2005) }\end{array}$ & $\begin{array}{l}\text { "A Comparison } \\
\text { of the } \\
\text { Effectiveness } \\
\text { of a Personal } \\
\text { Computer- } \\
\text { Based Aircraft } \\
\text { Training } \\
\text { Device and a } \\
\text { Flight Training } \\
\text { Device at } \\
\text { Improving Pilot } \\
\text { Instrument } \\
\text { Proficiency: A } \\
\text { Case Study in } \\
\text { Leading } \\
\text { Regulatory } \\
\text { Change in } \\
\text { Aviation } \\
\text { Education" }\end{array}$ & $\begin{array}{l}\text { training } \\
\text { proficiency } \\
\end{array}$ & QT & $\begin{array}{l}\text { between } \\
\text { groups } \\
\text { experiment }\end{array}$ & $\begin{array}{l}63 \text { IFR } \\
\text { pilots }\end{array}$ & $\begin{array}{l}\text { Experience } \\
\text { from }<250 \\
\text { to }>1500 \\
\text { hrs.; } \\
\text { Instrument } \\
\text { experience } \\
\text { from } \\
<10 \text { to }>250 \\
\text { hrs. }\end{array}$ & $\begin{array}{l}\text { maintain } \\
\text { ILS } \\
\text { proficiency } \\
\end{array}$ & $\begin{array}{l}\text { Precision } \\
\text { Flight } \\
\text { Controls } \\
\text { PCATD }\end{array}$ & $\begin{array}{l}\text { Frasca } \\
\text { FTD }\end{array}$ & & & $\begin{array}{l}\text { training } \\
\text { platform (two } \\
\text { levels) }\end{array}$ & $\begin{array}{l}\text { performance } \\
\text { associated } \\
\text { with IFR } \\
\text { flight } \\
\text { standards }\end{array}$ & & $\begin{array}{l}t \text {-tests, } \\
\text { ANOVA, } \\
\text { ANCOVA, } \\
\text { correlations }\end{array}$ & 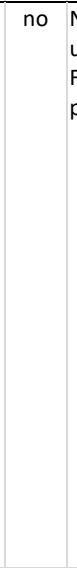 & $\begin{array}{l}\text { No difference in } \\
\text { using a PCATD or } \\
\text { FTD to maintain IFR } \\
\text { proficiency. }\end{array}$ \\
\hline $\begin{array}{l}\text { McLean et al. } \\
\text { (2016) }\end{array}$ & $\begin{array}{l}\text { "The Use of } \\
\text { Simulation in } \\
\text { Ab Initio Pilot } \\
\text { Training" }\end{array}$ & $\begin{array}{l}\text { training } \\
\text { proficiency }\end{array}$ & TT & $\begin{array}{l}\text { between } \\
\text { groups } \\
\text { experiment } \\
\text { with TER }\end{array}$ & $\begin{array}{l}91 \text { total: } 29 \\
\text { students in } \\
\text { a PPL } \\
\text { course, } \\
\text { historical } \\
\text { data from } \\
62 \text { students }\end{array}$ & $\begin{array}{l}\text { ab initio } \\
\text { flight } \\
\text { students } \\
\end{array}$ & $\begin{array}{l}\text { progression } \\
\text { through PPL } \\
\text { course to } \\
\text { standards }\end{array}$ & & $\begin{array}{l}\text { Redbird } \\
\text { FMX } \\
\text { AATD }\end{array}$ & & $\begin{array}{l}\text { Cessna } \\
172 S\end{array}$ & $\begin{array}{l}\text { training } \\
\text { platform; } \\
\text { Control group: } \\
\text { historical data; } \\
\text { Experimental } \\
\text { group: C172 } \\
\text { and AATD) }\end{array}$ & $\begin{array}{l}\text { time to reach } \\
\text { milestones }\end{array}$ & $\begin{array}{l}\text { recorded } \\
\text { simulator } \\
\text { parameters }\end{array}$ & TER & $\begin{array}{ll}\text { no } \\
8 \\
s \\
\text { t } \\
\text { a } \\
s \\
\text { i } \\
t \\
s\end{array}$ & $\begin{array}{l}\text { The treatment } \\
\text { group had } \\
\text { significantly fewer } \\
\text { training hours in } \\
\text { aircraft and a } \\
\text { significant increase } \\
\text { in overall training } \\
\text { time with the } \\
\text { simulator. }\end{array}$ \\
\hline $\begin{array}{l}\text { Mulder et al. } \\
\text { (2013) }\end{array}$ & $\begin{array}{l}\text { "A Cybernetic } \\
\text { Approach to } \\
\text { Assess } \\
\text { Simulator } \\
\text { Fidelity: } \\
\text { Looking Back } \\
\text { and Looking } \\
\text { Forward" }\end{array}$ & motion & QT & $\begin{array}{l}\text { multiple } \\
\text { experiments }\end{array}$ & $\begin{array}{l}\text { multiple } \\
\text { pilots }\end{array}$ & $\begin{array}{l}\text { not } \\
\text { described }\end{array}$ & $\begin{array}{l}\text { pitch and } \\
\text { roll attitude } \\
\text { tracking } \\
\text { tasks; in- } \\
\text { flight pilot } \\
\text { control } \\
\text { behavior }\end{array}$ & & $\begin{array}{l}\text { Cessna } \\
\text { Citation II } \\
\text { (C550) } \\
\text { sim. }\end{array}$ & SIMONA & & $\begin{array}{l}\text { training } \\
\text { platform; } \\
\text { multimodal } \\
\text { pilot models; } \\
\text { system } \\
\text { identification } \\
\text { and parameter } \\
\text { estimation } \\
\text { methods }\end{array}$ & $\begin{array}{l}\text { in-flight pilot } \\
\text { control } \\
\text { behavior } \\
\text { measured by } \\
\text { pitch and roll } \\
\text { attitude; } \\
\text { discrepancies } \\
\text { observed } \\
\text { between real } \\
\text { flight and } \\
\text { simulator }\end{array}$ & $\begin{array}{l}\text { recorded } \\
\text { simulator } \\
\text { parameters }\end{array}$ & $\begin{array}{l}\text { structural } \\
\text { mathematical } \\
\text { models }\end{array}$ & s & $\begin{array}{l}\text { Simulated motion } \\
\text { cueing should } \\
\text { approximate cueing } \\
\text { experienced in the } \\
\text { live task } \\
\text { environment to } \\
\text { enhance the } \\
\text { transfer of training. }\end{array}$ \\
\hline
\end{tabular}

Note. AATD/FTD $=$ advanced aviation training device/flight training device. BATD/PCATD $=$ basic aviation training device/personal computer-based aviation training device. FFS = full flight simulator. FFT = full flight trainer. IFR = instrument flight rules. ILS = instrument landing system. IT $=$ incremental transfer. $\mathrm{PPL}=$ private pilot license. sim. $=$ simulator. $\mathrm{QT}=$ quasi-transfer. $\mathrm{TER}=$ transfer effectiveness ratio. $\mathrm{TT}=$ true transfer. 


\section{Table B2 Continued}

Abstracted Data from 26 Airplane Transfer Studies

\begin{tabular}{|c|c|c|c|c|c|c|c|c|c|c|c|c|c|c|c|c|c|}
\hline Authors (Year) & Title & Theme & Type & $\begin{array}{l}\text { Research } \\
\text { Design }\end{array}$ & Participants & Experience & $\begin{array}{c}\text { Skills } \\
\text { Assessed }\end{array}$ & $\begin{array}{l}\text { BATD / } \\
\text { PCATD }\end{array}$ & $\begin{array}{l}\text { AATD / } \\
\text { FTD }\end{array}$ & FFS / FFT & Aircraft & $\begin{array}{c}\text { Independent } \\
\text { Variables }\end{array}$ & $\begin{array}{c}\text { Dependent } \\
\text { Measures }\end{array}$ & $\begin{array}{c}\text { Data } \\
\text { Collection }\end{array}$ & Analysis & $\begin{array}{c}\text { Effect } \\
\text { Size }\end{array}$ & $\begin{array}{c}\text { Chief } \\
\text { Results }\end{array}$ \\
\hline $\begin{array}{l}\text { Nieuwenhuizen } \\
\text { et al. (2013) }\end{array}$ & $\begin{array}{l}\text { "Influences of } \\
\text { Simulator } \\
\text { Motion System } \\
\text { Characteristics } \\
\text { on Pilot } \\
\text { Control } \\
\text { Behavior" }\end{array}$ & motion & $T T$ & $\begin{array}{l}\text { within } \\
\text { groups } 2 \times \\
2 \times 2 \\
\text { factorial } \\
\text { experiment }\end{array}$ & 9 pilots & $\begin{array}{l}\text { experience } \\
\text { with closed- } \\
\text { loop control } \\
\text { tasks; no } \\
\text { flight } \\
\text { experience } \\
\text { required }\end{array}$ & $\begin{array}{l}\text { pilot control } \\
\text { behavior }\end{array}$ & & $\begin{array}{l}\text { MPI } \\
\text { Stewart } \\
\text { platform }\end{array}$ & SIMONA & & $\begin{array}{l}\text { training } \\
\text { platform } \\
\text { conditions of } \\
\text { the model } \\
\text { (seven } \\
\text { crossed } \\
\text { factors) }\end{array}$ & $\begin{array}{l}\text { time-domain } \\
\text { signals for } \\
\text { pitch } \\
\text { attitudes, } \\
\text { tracking } \\
\text { errors, and } \\
\text { control } \\
\text { signals }\end{array}$ & $\begin{array}{l}\text { recorded } \\
\text { simulator } \\
\text { parameters }\end{array}$ & ANOVAs & no & $\begin{array}{l}\text { Simulator time } \\
\text { delay and noise } \\
\text { characteristics did } \\
\text { not impact pilot } \\
\text { behavior. Motion } \\
\text { system bandwidth } \\
\text { significantly } \\
\text { impacted } \\
\text { performance and } \\
\text { control behavior. }\end{array}$ \\
\hline $\begin{array}{l}\text { Nullmeyer et al. } \\
\text { (2006) }\end{array}$ & $\begin{array}{l}\text { "The } \\
\text { Effectiveness } \\
\text { of a PC-Based } \\
\text { C-130 Crew } \\
\text { Resource } \\
\text { Management } \\
\text { Aircrew } \\
\text { Training } \\
\text { Device" }\end{array}$ & $\begin{array}{l}\text { training } \\
\text { proficiency }\end{array}$ & TT & $\begin{array}{l}\text { between } \\
\text { groups } \\
\text { experiment }\end{array}$ & $\begin{array}{l}22 \text { total: } 11 \\
\text { student } \\
\text { right-seat } \\
\text { pilots and } \\
11 \text { student } \\
\text { navigators }\end{array}$ & $\begin{array}{l}\text { students in } \\
\text { tactical phase } \\
\text { of C-130 } \\
\text { mission } \\
\text { qualification } \\
\text { training, no } \\
\text { previous C- } \\
130 \text { or } \\
\text { airdrop } \\
\text { experience }\end{array}$ & $\begin{array}{l}\text { CRM skills and } \\
\text { proficiency (task } \\
\text { management, SA, } \\
\text { communication, } \\
\text { crew } \\
\text { coordination, } \\
\text { decision } \\
\text { making/risk } \\
\text { assessment, } \\
\text { mission planning, } \\
\text { aircraft handling) }\end{array}$ & $\begin{array}{l}\text { MS Flight } \\
\text { Simulator } \\
\text { C-130 } \\
\text { config. }\end{array}$ & & & $C-130$ & $\begin{array}{l}\text { treatment } \\
\text { condition; } \\
\text { survey } \\
\text { feedback }\end{array}$ & CRM skills & $\begin{array}{l}\text { surveys, } \\
\text { instructor } \\
\text { ratings, } \\
\text { training } \\
\text { records }\end{array}$ & $\begin{array}{l}\text { general } \\
\text { qualitative, } \\
t \text {-test, } \\
\text { MANOVA, } \\
\text { sign tests }\end{array}$ & no & $\begin{array}{l}\text { Significantly } \\
\text { higher CRM } \\
\text { performance } \\
\text { ratings, generally } \\
\text { higher } \\
\text { performance } \\
\text { grades, and fewer } \\
\text { iterations to meet } \\
\text { standards for the } \\
\text { treatment group } \\
\text { when compared } \\
\text { to the control } \\
\text { group. }\end{array}$ \\
\hline $\begin{array}{l}\text { Pool et al. } \\
\text { (2016) }\end{array}$ & $\begin{array}{l}\text { "Effects of } \\
\text { Simulator } \\
\text { Motion } \\
\text { Feedback on } \\
\text { Training of } \\
\text { Skill-Based } \\
\text { Control } \\
\text { Behavior" }\end{array}$ & motion & QT & $\begin{array}{l}\text { between- } \\
\text { subjects } \\
\text { experiment }\end{array}$ & 24 students & $\begin{array}{l}\text { no flight } \\
\text { experience; } \\
\text { groups } \\
\text { divided by } \\
\text { skill-based } \\
\text { manual } \\
\text { control } \\
\text { experience }\end{array}$ & $\begin{array}{l}\text { skill-based } \\
\text { compensatory } \\
\text { pitch tracking } \\
\text { task; tracking } \\
\text { performance and } \\
\text { control }\end{array}$ & & & SIMONA & & $\begin{array}{l}\text { training } \\
\text { platform } \\
\text { (two levels); } \\
\text { skill-based } \\
\text { manual } \\
\text { control } \\
\text { experience } \\
\text { (quasi } \\
\text { variable) }\end{array}$ & $\begin{array}{l}\text { time, error } \\
\text { signal, pitch } \\
\text { angle, } \\
\text { control input }\end{array}$ & $\begin{array}{l}\text { recorded } \\
\text { simulator } \\
\text { parameters }\end{array}$ & $\begin{array}{l}\text { Human- } \\
\text { operator } \\
\text { response } \\
\text { modeling } \\
\text { equations, } \\
\text { learning } \\
\text { curve } \\
\text { model } \\
\text { equation, } \\
\text { correlations }\end{array}$ & no & $\begin{array}{l}\text { Training groups } \\
\text { adapted behavior } \\
\text { and } \\
\text { demonstrated } \\
\text { positive yet } \\
\text { limited transfer } \\
\text { gains. }\end{array}$ \\
\hline $\begin{array}{l}\text { Pool \& Zaal } \\
\text { (2015) }\end{array}$ & $\begin{array}{l}\text { "Between- } \\
\text { Subject } \\
\text { Variability in } \\
\text { Transfer-of- } \\
\text { Training of } \\
\text { Skill-Based } \\
\text { Manual } \\
\text { Control } \\
\text { Behavior" }\end{array}$ & control & QT & $\begin{array}{l}\text { between- } \\
\text { subjects } \\
\text { experiment }\end{array}$ & $\begin{array}{l}\text { SIMONA } \\
\text { study: } 24 \\
\text { students; } \\
\text { AMES } \\
\text { study: } 19 \\
\text { GA pilots }\end{array}$ & $\begin{array}{l}\text { SIMONA: } \\
\text { none for } \\
\text { manual } \\
\text { control tasks. } \\
\text { AMES: } \\
\text { varying flight } \\
\text { experience }\end{array}$ & $\begin{array}{l}\text { performance, } \\
\text { control ability for } \\
\text { a tracking task }\end{array}$ & & & SIMONA & & $\begin{array}{l}\text { training } \\
\text { platform }\end{array}$ & $\begin{array}{l}\text { in-flight pilot } \\
\text { control } \\
\text { behavior } \\
\text { measured by } \\
\text { target } \\
\text { following } \\
\text { signal, roll, } \\
\text { pitch attitude }\end{array}$ & $\begin{array}{l}\text { recorded } \\
\text { flight } \\
\text { parameters } \\
\end{array}$ & $\begin{array}{l}\text { learning } \\
\text { curve } \\
\text { model, } \\
\text { TERs }\end{array}$ & no & $\begin{array}{l}\text { Post-transfer } \\
\text { effects were } \\
\text { noticed in both } \\
\text { studies when } \\
\text { there was no } \\
\text { motion, although } \\
\text { there were } \\
\text { differences in the } \\
\text { amount based on } \\
\text { pilot experience }\end{array}$ \\
\hline
\end{tabular}

Note. AATD/FTD = advanced aviation training device/flight training device. BATD/PCATD = basic aviation training device/personal computer-based aviation training device. config. = configuration. $\mathrm{CRM}=$ crew resource management. FFS = full flight simulator. FFT = full flight trainer. GA = general aviation. QT $=$ quasi-transfer. $\mathrm{SA}=$ situation awareness. $\mathrm{TER}=$ transfer effectiveness ratio. $\mathrm{TT}=$ true transfer. 
Neal et al:: Recommendations from the Airplane Simulation Transfer Literature

Table B2 Continued

Abstracted Data from 26 Airplane Transfer Studies

\begin{tabular}{|c|c|c|c|c|c|c|c|c|c|c|c|c|c|c|c|c|c|}
\hline $\begin{array}{l}\text { Authors } \\
\text { (Year) }\end{array}$ & Title & Theme & Type & $\begin{array}{l}\text { Research } \\
\text { Design }\end{array}$ & Participants & Experience & $\begin{array}{c}\text { Skills } \\
\text { Assessed }\end{array}$ & $\begin{array}{l}\text { BATD / } \\
\text { PCATD }\end{array}$ & $\begin{array}{c}\text { AATD / } \\
\text { FTD }\end{array}$ & $\begin{array}{l}\mathrm{FFS} / \\
\mathrm{FFT}\end{array}$ & Aircraft & $\begin{array}{c}\text { Independent } \\
\text { Variables }\end{array}$ & $\begin{array}{l}\text { Dependent } \\
\text { Measures }\end{array}$ & $\begin{array}{c}\text { Data } \\
\text { Collection }\end{array}$ & Analysis & $\begin{array}{c}\text { Effect } \\
\text { Size }\end{array}$ & $\begin{array}{l}\text { Chief } \\
\text { Results }\end{array}$ \\
\hline $\begin{array}{l}\text { Reweti } \\
\text { (2014) }\end{array}$ & $\begin{array}{l}\text { "PC-based } \\
\text { Aviation } \\
\text { Training Devices } \\
\text { for Pilot Training } \\
\text { in Visual Flight } \\
\text { Rules } \\
\text { Procedures: } \\
\text { Development, } \\
\text { Validation and } \\
\text { Effectiveness" }\end{array}$ & $\begin{array}{l}\text { training } \\
\text { proficiency }\end{array}$ & QT & $\begin{array}{l}\text { between } \\
\text { groups } \\
\text { experiment }\end{array}$ & 93 pilots & $\begin{array}{l}\text { ab initio in } \\
\text { one cohort; } \\
\text { various } \\
\text { experience } \\
\text { in another } \\
\text { (B737-800, } \\
\text { helicopter, } \\
\text { military, } \\
\text { glider; CFIs) }\end{array}$ & $\begin{array}{l}\text { VFR and IFR } \\
\text { task } \\
\text { performance }\end{array}$ & $\begin{array}{l}\text { custom- } \\
\text { created, } \\
\text { SAV2 PCATD } \\
\text { with PA28 } \\
\text { configuration }\end{array}$ & $\begin{array}{l}\text { Frasca } \\
\text { TruFlight } 1 \\
\text { FTDs: } \\
\text { PA28 } \\
\text { Warrior, } \\
\text { Cessna }\end{array}$ & $\begin{array}{l}\text { Cessna } \\
172 \\
\text { config. }\end{array}$ & & $\begin{array}{l}\text { training } \\
\text { platform } \\
\text { (three } \\
\text { levels); } \\
\text { experience } \\
\text { (quasi } \\
\text { variable) }\end{array}$ & $\begin{array}{l}\text { VFR and IFR } \\
\text { performance } \\
\text { and } \\
\text { proficiency }\end{array}$ & $\begin{array}{l}\text { recorded } \\
\text { simulator } \\
\text { parameters }\end{array}$ & $\begin{array}{l}\text { one way } \\
\text { between, } 3 \times 2 \\
\text { mixed model } \\
\text { ANOVA; one- } \\
\text { way } \\
\text { between, } 2 \times 2 \\
\text { mixed model } \\
\text { ANOVA }\end{array}$ & $\begin{array}{l}\mathrm{N} \\
\mathrm{p} \\
\mathrm{i} \\
\mathrm{F} \\
\mathrm{F} \\
\mathrm{in} \\
\mathrm{c} \\
\mathrm{u}\end{array}$ & $\begin{array}{l}\text { No difference in task } \\
\text { performance between } \\
\text { training on PCATD and } \\
\text { FTD. Significant } \\
\text { improvements } \\
\text { compared to control } \\
\text { with no simulation. }\end{array}$ \\
\hline $\begin{array}{l}\text { Reweti et } \\
\text { al. (2017) }\end{array}$ & $\begin{array}{l}\text { "Efficacy of Low- } \\
\text { Cost PC-Based } \\
\text { Aviation } \\
\text { Training } \\
\text { Devices" }\end{array}$ & $\begin{array}{l}\text { training } \\
\text { proficiency }\end{array}$ & QT & $\begin{array}{l}\text { between } \\
\text { groups } \\
\text { experiment }\end{array}$ & 93 pilots & $\begin{array}{l}\text { ab initio in } \\
\text { one cohort; } \\
\text { various } \\
\text { experience } \\
\text { in another } \\
\text { (B737-800, } \\
\text { helicopter, } \\
\text { military, } \\
\text { glider; CFIs) }\end{array}$ & $\begin{array}{l}\text { VFR and IFR } \\
\text { task } \\
\text { performance }\end{array}$ & $\begin{array}{l}\text { custom- } \\
\text { created, } \\
\text { SAV2 PCATD } \\
\text { with PA28 } \\
\text { configuration }\end{array}$ & $\begin{array}{l}\text { Frasca } \\
\text { TruFlight } \\
\text { FTDs: } \\
\text { PA28 } \\
\text { Warrior, } \\
\text { Cessna } \\
172 \\
\text { config. }\end{array}$ & & & $\begin{array}{l}\text { training } \\
\text { platform } \\
\text { (three } \\
\text { levels); } \\
\text { experience } \\
\text { (quasi } \\
\text { variable) }\end{array}$ & $\begin{array}{l}\text { VFR and IFR } \\
\text { performance } \\
\text { and } \\
\text { proficiency }\end{array}$ & $\begin{array}{l}\text { recorded } \\
\text { simulator } \\
\text { parameters }\end{array}$ & $\begin{array}{l}\text { one way } \\
\text { between, } 3 \times 2 \\
\text { mixed model } \\
\text { ANOVA; one- } \\
\text { way } \\
\text { between, } 2 \times 2 \\
\text { mixed model } \\
\text { ANOVA }\end{array}$ & $\begin{array}{ll}n \\
p \\
p \\
t \\
F \\
\text { ir } \\
c \\
\text { n }\end{array}$ & $\begin{array}{l}\text { No difference in task } \\
\text { performance between } \\
\text { training on PCATD and } \\
\text { FTD. Significant } \\
\text { improvements } \\
\text { compared to control } \\
\text { with no simulation. }\end{array}$ \\
\hline $\begin{array}{l}\text { Roessingh } \\
\text { (2005) }\end{array}$ & $\begin{array}{l}\text { "Transfer of } \\
\text { Manual Flying } \\
\text { Skills from PC- } \\
\text { Based } \\
\text { Simulation to } \\
\text { Actual Flight- } \\
\text { Comparison of } \\
\text { In-Flight } \\
\text { Measured Data } \\
\text { and Instructor } \\
\text { Ratings" }\end{array}$ & $\begin{array}{l}\text { training } \\
\text { proficiency }\end{array}$ & $\pi T$ & $\begin{array}{l}\text { between } \\
\text { groups } \\
\text { experiment }\end{array}$ & $\begin{array}{l}21 \text { student } \\
\text { pilots }\end{array}$ & $\begin{array}{l}\text { students } \\
\text { grouped by } \\
\text { ability score } \\
\text { of Aiming } \\
\text { Screening } \\
\text { Task }\end{array}$ & $\begin{array}{l}\text { Skill level } \\
\text { accuracy of } \\
\text { each } \\
\text { maneuver } \\
\text { flown; } \\
\text { Training } \\
\text { Goal: fly five } \\
\text { aerobatic } \\
\text { maneuvers }\end{array}$ & $\begin{array}{l}\text { generic, } \\
\text { similar to } \\
\text { Bellanca } \\
\text { configuration }\end{array}$ & & & $\begin{array}{l}\text { Bellanca } \\
\text { Super } \\
\text { Decathlon } \\
\\
\end{array}$ & $\begin{array}{l}\text { training } \\
\text { platform; } \\
\text { lesson } \\
\text { number as a } \\
\text { covariate; } \\
\text { data files; } \\
\text { instructor } \\
\text { presence }\end{array}$ & $\begin{array}{l}\text { performance } \\
\text { scores }\end{array}$ & $\begin{array}{l}\text { recorded } \\
\text { simulator } \\
\text { parameters }\end{array}$ & $\begin{array}{l}\text { two-tailed } t \text { - } \\
\text { test, the } \\
\text { accuracy of } \\
\text { maneuver } \\
\text { determined } \\
\text { by specified } \\
\text { criteria, } \\
\text { learning } \\
\text { curves, } \\
\text { regression } \\
\text { analyses }\end{array}$ & $\begin{array}{ll}\text { no } & \text { d } \\
d \\
s \\
t \\
t \\
s \\
n \\
r \\
p \\
\text { p }\end{array}$ & $\begin{array}{l}\text { No significant } \\
\text { differences in flying } \\
\text { skills between the } \\
\text { three groups, although } \\
\text { treatment groups flew } \\
\text { significantly more } \\
\text { maneuvers and } \\
\text { received higher } \\
\text { performance } \\
\text { evaluations. }\end{array}$ \\
\hline $\begin{array}{l}\text { Rogers et } \\
\text { al. (2009); } \\
\text { Rogers et } \\
\text { al. (2010) }\end{array}$ & $\begin{array}{l}\text { "An Experiment } \\
\text { to Evaluate } \\
\text { Transfer of Low- } \\
\text { Cost Simulator- } \\
\text { Based Upset- } \\
\text { Recovery } \\
\text { Training" }\end{array}$ & $\begin{array}{l}\text { abnormal / } \\
\text { unexpected } \\
\text { events }\end{array}$ & $\pi$ & $\begin{array}{l}2 \times 4 \\
\text { repeated } \\
\text { measures } \\
\text { factorial }\end{array}$ & $\begin{array}{l}51 \\
\text { instrument- } \\
\text { rated PPL: } \\
25 \text { trained } \\
\text { and } 26 \\
\text { control } \\
\text { participants }\end{array}$ & $\begin{array}{l}\text { IFR PPL, no } \\
\text { prior } \\
\text { aerobatic } \\
\text { or URT }\end{array}$ & $\begin{array}{l}\text { upset } \\
\text { recovery }\end{array}$ & $\begin{array}{l}\text { MS Flight } \\
\text { Simulator } \\
2002 \text { desktop } \\
\text { software }\end{array}$ & & & $\begin{array}{l}\text { Beech } \\
\text { Bonanza } \\
\text { \&Super } \\
\text { Decathlon } \\
\text { aerobatic } \\
\text { trainer }\end{array}$ & $\begin{array}{l}\text { degree-of- } \\
\text { training (two } \\
\text { levels) and } \\
\text { upset } \\
\text { attitude (four } \\
\text { levels) } \\
\end{array}$ & $\begin{array}{l}\text { altitude loss, } \\
\text { maximum G- } \\
\text { force in dive } \\
\text { pullout, } \\
\text { minimum G- } \\
\text { force } \\
\text { unloading in } \\
\text { rolls, } \\
\text { response } \\
\text { times }\end{array}$ & $\begin{array}{l}\text { recorded } \\
\text { simulator } \\
\text { and flight } \\
\text { parameters }\end{array}$ & $\begin{array}{l}\text { Wilks' } \\
\text { Lambda, } \\
\text { ANOVA }\end{array}$ & $\begin{array}{l}T \\
s \\
\text { t } \\
o\end{array}$ & $\begin{array}{l}\text { Treatment group } \\
\text { significantly exceeded } \\
\text { the control group in } 16 \\
\text { of } 23 \text { categories }\end{array}$ \\
\hline
\end{tabular}

Note. AATD/FTD = advanced aviation training device/flight training device. BATD/PCATD = basic aviation training device/personal computer-based aviation training device. $\mathrm{CFI}=$ certificated flight instructor. config. = configuration. FFS $=$ full flight simulator. FFT $=$ full flight trainer. IFR $=$ instrument flight rules. $\mathrm{PPL}=$ private pilot license. $\mathrm{QT}=$ quasi-transfer. $\mathrm{TT}=$ true transfer. URT $=$ upset recovery training. VFR $=$ visual flight rules. 


\section{Table B2 Continued}

Abstracted Data from 26 Airplane Transfer Studies

\begin{tabular}{|c|c|c|c|c|c|c|c|c|c|c|c|c|c|c|c|c|c|}
\hline $\begin{array}{c}\text { Authors } \\
\text { (Year) }\end{array}$ & Title & Theme & Type & $\begin{array}{l}\text { Research } \\
\text { Design }\end{array}$ & Participants & Experience & $\begin{array}{c}\text { Skills } \\
\text { Assessed }\end{array}$ & $\begin{array}{l}\text { BATD / } \\
\text { PCATD }\end{array}$ & AATD / FTD & FFS / FFT & Aircraft & $\begin{array}{c}\text { Independent } \\
\text { Variables }\end{array}$ & $\begin{array}{l}\text { Dependent } \\
\text { Measures }\end{array}$ & $\begin{array}{c}\text { Data } \\
\text { Collection }\end{array}$ & Analysis & $\begin{array}{c}\text { Effect } \\
\text { Size }\end{array}$ & $\begin{array}{c}\text { Chief } \\
\text { Results } \\
\end{array}$ \\
\hline $\begin{array}{l}\text { Sparko et } \\
\text { al. (2010) }\end{array}$ & $\begin{array}{l}\text { "Transfer of } \\
\text { Training from } \\
\text { a Full-Flight } \\
\text { Simulator vs. } \\
\text { a High-Level } \\
\text { Flight Training } \\
\text { Device with a } \\
\text { Dynamic Seat" }\end{array}$ & motion & QT & $\begin{array}{l}\text { between } \\
\text { groups } \\
\text { experiment }\end{array}$ & 40 pilots & $\begin{array}{l}\text { low exp } \\
\text { pilots } \\
\text { (<500 hrs.); } \\
20 \mathrm{FFS}- \\
\text { trained and } \\
20 \mathrm{FFT}- \\
\text { trained }\end{array}$ & $\begin{array}{l}2 \text { continued } \\
\text { takeoffs } \\
\text { with engine } \\
\text { failure and } \\
2 \text { manual } \\
\text { engine-out } \\
\text { landing } \\
\text { maneuvers }\end{array}$ & & $\begin{array}{l}\text { Mechtronix } \\
\text { with } \\
\text { dynamic } \\
\text { seat }\end{array}$ & $\begin{array}{l}\text { Thompson } \\
\text { turboprop } \\
\text { with two } \\
\text { wing- } \\
\text { mounted } \\
\text { engines }\end{array}$ & & $\begin{array}{l}\text { training } \\
\text { platform } \\
\text { (two levels) }\end{array}$ & $\begin{array}{l}109 \text { variables } \\
\text { (flight } \\
\text { precision \& } \\
\text { control } \\
\text { inputs) in the } \\
\text { FFS \& } 90 \\
\text { variables in } \\
\text { the FFT }\end{array}$ & $\begin{array}{l}\text { recorded } \\
\text { simulator } \\
\text { parameters }\end{array}$ & $\begin{array}{l}\text { box-cox } \\
\text { power- } \\
\text { transform for } \\
\text { normality; } \\
\text { MANOVA } \\
\text { (GLM)- } \\
\text { multivariate } \\
\text { repeated } \\
\text { measures }\end{array}$ & no & $\begin{array}{l}\text { Group differences } \\
\text { in performance } \\
\text { precision and } \\
\text { training } \\
\text { disappeared upon } \\
\text { transfer to the FFS. }\end{array}$ \\
\hline $\begin{array}{l}\text { Svensson et } \\
\text { al. (2013) }\end{array}$ & $\begin{array}{l}\text { "Skill Decay, } \\
\text { Re-Acquisition } \\
\text { Training, and } \\
\text { Transfer } \\
\text { Studies in the } \\
\text { Swedish Air } \\
\text { Force: A } \\
\text { Retrospective } \\
\text { Review" }\end{array}$ & $\begin{array}{l}\text { training } \\
\text { proficiency }\end{array}$ & TT & $\begin{array}{l}\text { repeated } \\
\text { measures }\end{array}$ & $\begin{array}{l}\text { Simulation } \\
\text { study: } 16 \\
\text { pilots } \\
\text { (treatment); } \\
35 \text { active } \\
\text { pilots } \\
\text { (control) } \\
\text { study and } 6 \\
\text { of the pilots } \\
\text { in the } \\
\text { transfer } \\
\text { study }\end{array}$ & $\begin{array}{l}\text { Retired } \\
\text { fighter } \\
\text { pilots: } 6 \\
\text { months - } \\
12 \text { years } \\
\text { since flying } \\
\text { the JA35; } \\
\text { active JA35 } \\
\text { pilots; } \\
\text { flight } \\
\text { experience } \\
380-2400 \\
\text { hrs. }\end{array}$ & $\begin{array}{l}\text { aircraft, } \\
\text { radar, and } \\
\text { weapon } \\
\text { systems } \\
\text { operations }\end{array}$ & & & $\begin{array}{l}\text { JA35 } \\
\text { Draken } \\
\text { single-seat } \\
\text { fighter jet }\end{array}$ & $\begin{array}{l}\text { JA35 } \\
\text { Draken } \\
\text { single-seat } \\
\text { fighter jet }\end{array}$ & $\begin{array}{l}\text { speed of skill } \\
\text { decay, re- } \\
\text { acquisition } \\
\text { training, } \\
\text { transfer of } \\
\text { training } \\
\text { performance }\end{array}$ & 78 variables & $\begin{array}{l}\text { 1: recorded } \\
\text { simulator } \\
\text { and flight } \\
\text { parameters } \\
\text { 2: instructor } \\
\text { measures of } \\
\text { pilot } \\
\text { performance } \\
\text { and self- } \\
\text { ratings of } \\
\text { mental } \\
\text { effort, } \\
\text { motivation, } \\
\text { mood }\end{array}$ & $\begin{array}{l}\text { structural } \\
\text { equation } \\
\text { modeling; } \\
\text { factor } \\
\text { analysis of } \\
\text { linear } \\
\text { relationships; } \\
\text { intra-subject } \\
\text { and inter- } \\
\text { subject } \\
\text { variance; }\end{array}$ & yes & $\begin{array}{l}\text { 1: Experimental } \\
\text { group had lower } \\
\text { performance } \\
\text { before training than } \\
\text { after, but no } \\
\text { differences } \\
\text { between groups } \\
\text { after training. } \\
\text { \#2: Significant } \\
\text { transfer effect, but } \\
\text { no difference } \\
\text { between training } \\
\text { and aircraft } \\
\text { performance; skill } \\
\text { decay is a better } \\
\text { predictor of } \\
\text { performance than } \\
\text { time on the system. }\end{array}$ \\
\hline $\begin{array}{l}\text { Taylor et al. } \\
\text { (2004) }\end{array}$ & $\begin{array}{l}\text { "The } \\
\text { Effectiveness } \\
\text { of a Personal } \\
\text { Computer } \\
\text { Aviation } \\
\text { Training } \\
\text { Device } \\
\text { (PCATD), a } \\
\text { Flight Training } \\
\text { Device (FTD), } \\
\text { and an } \\
\text { Airplane in } \\
\text { Conducting } \\
\text { Instrument } \\
\text { Proficiency } \\
\text { Checks" }\end{array}$ & $\begin{array}{l}\text { training } \\
\text { proficiency }\end{array}$ & TT & $\begin{array}{l}\text { between } \\
\text { groups } \\
\text { experiment }\end{array}$ & 75 IFR pilots & $\begin{array}{l}\text { most with } \\
\text { current } \\
\text { instrument } \\
\text { experience }\end{array}$ & $\begin{array}{l}\text { flight } \\
\text { maneuvers } \\
\text { associated } \\
\text { with IFR } \\
\text { proficiency }\end{array}$ & $\begin{array}{l}\text { Elite } \\
\text { PCATD } \\
\end{array}$ & $\begin{array}{l}\text { Frasca } 141 \\
\text { FTD }\end{array}$ & & $\begin{array}{l}\text { Beechcraft } \\
\text { Sundowner } \\
\text { (BE-C23) }\end{array}$ & $\begin{array}{l}\text { training } \\
\text { platform } \\
\text { (three levels) }\end{array}$ & $\begin{array}{l}\text { performance } \\
\text { of instrument } \\
\text { flight } \\
\text { standards for } \\
\text { proficiency }\end{array}$ & $\begin{array}{l}\text { instructor } \\
\text { scores IPC1 \& } \\
\text { IPC2 }\end{array}$ & $\begin{array}{l}\text { Chi-square of } \\
\% \text { pass/fail } \\
\text { pretest- } \\
\text { posttest } \\
\text { reliability }\end{array}$ & no & $\begin{array}{l}\text { No significant } \\
\text { differences in the } \\
\text { performances of } \\
\text { instrument pilots } \\
\text { on an IPC in either a } \\
\text { PCATD and FTD or } \\
\text { an airplane. }\end{array}$ \\
\hline
\end{tabular}

Note. AATD/FTD $=$ advanced aviation training device/flight training device. BATD/PCATD $=$ basic aviation training device/personal computer-based aviation training device. FFS $=$ full flight simulator. FFT $=$ full flight trainer. IFR $=$ instrument flight rules. IPC $=$ instrument proficiency check. QT $=$ quasi-transfer. $\mathrm{TT}=$ true transfer. 


\section{Table B2 Continued}

Abstracted Data from 26 Airplane Transfer Studies

\begin{tabular}{|c|c|c|c|c|c|c|c|c|c|c|c|c|c|c|c|c|c|}
\hline $\begin{array}{l}\text { Authors } \\
\text { (Year) }\end{array}$ & Title & Theme & Type & $\begin{array}{c}\text { Research } \\
\text { Design }\end{array}$ & Participants & Experience & $\begin{array}{c}\text { Skills } \\
\text { Assessed }\end{array}$ & $\begin{array}{l}\text { BATD / } \\
\text { PCATD }\end{array}$ & $\begin{array}{c}\text { AATD / } \\
\text { FTD }\end{array}$ & FFS / FFT & Aircraft & $\begin{array}{c}\text { Independent } \\
\text { Variables }\end{array}$ & $\begin{array}{l}\text { Dependent } \\
\text { Measures }\end{array}$ & $\begin{array}{c}\text { Data } \\
\text { Collection }\end{array}$ & Analysis & $\begin{array}{l}\text { Effect } \\
\text { Size }\end{array}$ & $\begin{array}{c}\text { Chief } \\
\text { Results }\end{array}$ \\
\hline $\begin{array}{l}\text { Taylor et al. } \\
\text { (2005) }\end{array}$ & $\begin{array}{l}\text { "Transfer of } \\
\text { Training } \\
\text { Effectiveness } \\
\text { of a Flight } \\
\text { Training } \\
\text { Device (FTD)" }\end{array}$ & $\begin{array}{l}\text { training } \\
\text { proficiency }\end{array}$ & IT & $\begin{array}{l}\text { between } \\
\text { groups } \\
\text { experiment }\end{array}$ & $\begin{array}{l}106 \text { student } \\
\text { pilots }\end{array}$ & $\begin{array}{l}\text { instrument } \\
\text { flight } \\
\text { students }\end{array}$ & $\begin{array}{l}\text { basic \& } \\
\text { advanced } \\
\text { instrument } \\
\text { PTS skills }\end{array}$ & $\begin{array}{l}\text { Elite } \\
\text { Piper } \\
\text { Archer } \\
\text { III }\end{array}$ & $\begin{array}{l}\text { Frasca } \\
141 \text { FTD }\end{array}$ & & $\begin{array}{l}\text { Piper } \\
\text { Archer } \\
\text { III }\end{array}$ & $\begin{array}{l}\text { training } \\
\text { platform } \\
\text { (three levels) }\end{array}$ & $\begin{array}{l}\text { number of } \\
\text { trials to } \\
\text { completion } \\
\text { standard in the } \\
\text { airplane, total } \\
\text { course time, } \\
\text { time to } \\
\text { successful } \\
\text { check }\end{array}$ & $\begin{array}{l}\text { instructor } \\
\text { scores }\end{array}$ & $\begin{array}{l}\text { TER, ITER, } \\
\% \text { transfer, } \\
\text { ANOVA* } \\
\text { (insufficient } \\
\text { data for } \\
\text { statistical } \\
\text { analysis) }\end{array}$ & no & $\begin{array}{l}\text { FTDs and PCATD are } \\
\text { effective in teaching } \\
\text { basic and advanced } \\
\text { instrument tasks to } \\
\text { private pilots. }\end{array}$ \\
\hline $\begin{array}{l}\text { Zaal et al. } \\
\text { (2015) }\end{array}$ & $\begin{array}{l}\text { "Transfer of } \\
\text { Training on the } \\
\text { Vertical } \\
\text { Motion } \\
\text { Simulator" }\end{array}$ & motion & QT & $\begin{array}{l}\text { between- } \\
\text { subjects } \\
\text { experiment }\end{array}$ & $\begin{array}{l}61 \text { general } \\
\text { aviation } \\
\text { pilots }\end{array}$ & $\begin{array}{l}35 \text { PPL, } 26 \\
\text { CPL, } 40 \text { IFR; } \\
\text { no } \\
\text { experience } \\
\text { with } \\
\text { commercial } \\
\text { transport } \\
\text { aircraft; } \\
\text { experience } \\
\text { ranged } \\
\text { from }>2000 \\
\text { hrs. to } \\
<10000 \text { hrs }\end{array}$ & $\begin{array}{l}\text { performance } \\
\text { of four } \\
\text { challenging } \\
\text { commercial } \\
\text { transport } \\
\text { tasks } \\
\end{array}$ & & & $\begin{array}{l}\text { NASA Ames } \\
\text { Vertical } \\
\text { Motion } \\
\text { Simulator, } \\
\text { transport cab } \\
\text { configuration }\end{array}$ & & $\begin{array}{l}\text { training } \\
\text { platform } \\
\text { (four levels) }\end{array}$ & $\begin{array}{l}\text { four subjective } \\
\text { dependent } \\
\text { measures and } \\
13 \text { objective } \\
\text { dependent } \\
\text { measures }\end{array}$ & $\begin{array}{l}\text { survey of } \\
\text { subjective } \\
\text { DVs and } \\
\text { recorded } \\
\text { simulator } \\
\text { parameters } \\
\text { for objective } \\
\text { DVs }\end{array}$ & $\begin{array}{l}\text { one way } \\
\text { ANOVA }\end{array}$ & no & $\begin{array}{l}\text { Motion training } \\
\text { resulted in positive } \\
\text { transfer for landing } \\
\text { and stall related tasks, } \\
\text { but the transfer was } \\
\text { negative for landing } \\
\text { tasks, upset recovery, } \\
\text { pedal reaction times. }\end{array}$ \\
\hline
\end{tabular}

Note. AATD/FTD $=$ advanced aviation training device/flight training device. BATD/PCATD $=$ basic aviation training device/personal computer-based aviation training device. $\mathrm{CPL}=$ commercial pilot license. $\mathrm{FFT}=$ full flight trainer. $\mathrm{FFS}=$ full flight simulator. IFR $=$ instrument flight rules. IT $=$ incremental transfer. $\mathrm{PTS}=$ practical training standards. QT $=$ quasi-transfer. 